\title{
A formação da rede urbana como estratégia de definição da fronteira entre as Capitanias de Minas Gerais e de São Paulo na segunda metade do século XVIII
}

Dossier REDE URBANA E DEFINIÇÃo dAS FRONTEIRAS PAULISTAS

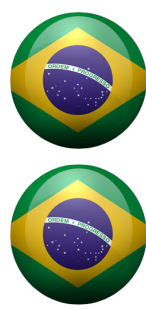

\section{Ivone Salgado}

Professora Titular da Pontifícia Universidade Católica de Campinas (FAU e POSURB). Arquiteta Urbanista, Doutorado pelo Institut d'Urbanisme de Paris - Université de Paris XII e Pós-doutorado junto ao Istituto Universitario di Architettura di Venezia. Campinas [SP] Brasil <salgadoivone@puc-campinas.edu.br>.

\section{Renata Baesso Pereira}

Professora Titular da Pontifícia Universidade Católica de Campinas (FAU e POSURB). Arquiteta Urbanista, Doutora pelo Programa de Pós Graduação da FAU USP, Mestre em Urbanismo pela PUC Campinas. Campinas [SP] Brasil <renata.baesso@puc-campinas.edu.br>.

\section{Resumo}

As instituições municipais são instrumentos essenciais na consolidação e defesa dos territórios da Coroa portuguesa no Brasil. No século XVIII, frente às descobertas auríferas e a ocupação do território, a criação de vilas em Minas Gerais configura-se como estratégia de afirmação do poder da Coroa e de organização administrativa. Quando a Capitania de São Paulo é restaurada, em 1765, o fortalecimento do poder da Coroa se estrutura por ações militares e pela inauguração da produção de açúcar, associada à criação de uma rede de povoados, freguesias e vilas. Os governadores paulistas buscam aprimorar estruturas que garantiriam os fluxos de pessoas e mercadorias no território, bem como consolidar os limites com os domínios da Espanha e com as capitanias confinantes. Contudo, a ocupação das áreas de fronteira, entre as capitanias de São Paulo e de Minas Gerais, nunca foi consensual entre as autoridades, tanto metropolitanas quanto coloniais. Região de litígio no século XVIII, o sertão do Rio das Mortes foi marcado por estabelecimentos paulistas, estimulados pelo governo desta capitania, e pelas tentativas de ordenamento das autoridades coloniais mineiras. 0 trabalho analisa conflitos, práticas e discursos envolvidos no processo de constituição da rede urbana, na região de fronteira, entre as capitanias de Minas Gerais e São Paulo, no final do século XVIII. As ações da Coroa indicam a importância da região, no final do século XVIII. Destaca-se o papel dos agentes do poder civil e eclesiástico no estabelecimento dos núcleos urbanos em questão.Os estudos de caso elucidam diferenças regionais em um mesmo contexto e fundamentam-se na documentação primária que representa os instrumentos de controle do território, por parte da Coroa: a cartografia e os ofícios das Câmaras e dos Governadores.

\section{Palavras-chave}

Capitania de São Paulo. Capitania de Minas Gerais. Rede urbana. Fronteiras. Século XVIII.

\section{The formation of the urban network as a strategy to define the boundary between the captaincies of Minas Gerais and São Paulo in the second half of the 18th century}

\begin{abstract}
The municipal institutions are essential instruments in the consolidation and defense of the territories of the Portuguese Crown in Brazil. In the 18th century, in face of the gold discoveries and occupation of the territory, the creation of towns in Minas Gerais is a strategy to affirm the Crown's power and administrative organization. When the Captaincy of São Paulo was restored in 1765, the strengthening of the Crown's power was structured by military actions and the inauguration of sugar production, which is associated with the creation of a network of villages, parishes and towns. The governors of São Paulo seek to improve structures that would guarantee the flows of people and goods in the territory, as well as consolidate territorial limits with Spain and with the confining captaincies. However, the occupation of the border areas between the captaincies of São Paulo and Minas Gerais was never consensual among the authorities, both metropolitan and colonial. A region of litigation in the18th century, the hinterland of the Rio das Mortes was marked by São Paulo's establishments, stimulated by the government of this captaincy, and by attempts to organize the colonial authorities of Minas Gerais. This work analyzes the conflicts, practices, and discourses involved in the process of establishing the urban network in the border region between the captaincies of Minas Gerais and São Paulo in the end of the $18^{\text {th }}$ century. The actions of the Crown indicate the importance of the region in the late eighteenth century. The role of civil and ecclesiastical authorities in the establishment of the urban centers in question is highlighted. The case studies elucidate regional differences in the same context and are based on the primary documentation that represents the instruments of control of the territory by the Crown: cartography and the oficial documents of the Municipal Chambers and the Governors.
\end{abstract}

\section{Keywords}

Captaincy of Sao Paulo. Captaincy of Minas Gerais. Urban network. Borders. $18^{\text {th }}$ century. 


\title{
1. Introdução: A formação da Capitania de São Paulo e Minas do Ouro e seus desmembramentos
}

As instituições municipais são instrumentos essenciais na consolidação e defesa dos territórios da Coroa portuguesa no Brasil. No século XVIII, em face das descobertas auríferas e da necessidade de ocupação do território, a criação de vilas em Minas Gerais configura-se como estratégia de afirmação do poder da Coroa e de organização administrativa.

A atividade de mineração, na região das minas gerais, desenvolvida entre os séculos XVII e XVIII, foi o fator determinante de uma ocupação mais densa no interior do território da colônia. No início do processo de mineração, no final do século XVII, Portugal ainda não tinha controle sobre a região das minas e a Coroa se preocupava apenas com a cobrança do "quinto". Os descobertos despertaram cobiça e atraíram gente de toda sorte, da colônia e do Reino. Sertão adentro imperavam desmandos, conflitos e os arraiais mineradores, no século XVII e início do XVIII, eram terra sem lei e sem ordem.

Em 1709, em função das descobertas auríferas, e com o objetivo de controlar efetivamente a região que mais crescia em importância aos olhos metropolitanos, a Coroa reincorporou, por compra, os territórios já bastante dilatados das antigas capitanias de São Vicente e Santo Amaro, criando a nova Capitania de São Paulo e Minas do Ouro (Bueno, 2009, p. 268). A vila de São Paulo dos Campos de Piratininga, elevada à condição de cidade em 24 de julho de 1711, foi escolhida como sede da nova Capitania.

\begin{abstract}
Em 1711, a Coroa também iniciou franca política de urbanização na região das minas de Cataguazes, aspirando a assegurar o controle da área mais valiosa da América portuguesa, agrupando indivíduos em povoados consolidados, reduzindo assim as possibilidades de contrabando. Sob o discurso ideológico de que a ereção de vilas era o melhor meio de "civilizar" e "desenvolver os rudes povoados", o programa do governo, num curto período de sete anos, condicionou a criação de oito novas vilas no território das Minas Gerais: Sabará, N. S. do Carmo (Mariana) e Vila Rica, em 1711; São João del Rey, em 1712; Vila do Príncipe (Serro Frio) e Vila Nova da Rainha do Caeté, em 1714; Vila Nova do Infante (Pitangui), em 1715; e São José del Rey (Tiradentes), em 1718. (Bueno, 2009, p. 272).
\end{abstract}

A dificuldade para controlar tão vasto território levou a Coroa a dividir a Capitania de São Paulo e Minas do Ouro. A permanência do Governador da Capitania de São Paulo e Minas do Ouro em Vila Rica acarretava prejuízos à comarca de São Paulo, mas se justificava pelo enriquecimento do Distrito das Minas. As decisões administrativas não tinham a devida eficácia e aos requerimentos não era dado pronto despacho. A separação da Capitania de São Paulo se efetivou, em 1720, durante o governo do Conde Assumar que, com a separação, continuou a governar a Capitania de Minas. Para governar a capitania de São Paulo foi designado Dom Rodrigo César de Menezes, que a governou entre 1721 e1727.

A divisa entre as duas capitanias deveria ser então a mesma fixada entre as comarcas do Rio das Mortes e de São Paulo: a Serra da Mantiqueira1. Prevendo os litígios pelos limites das duas circunscrições, foi declarado pela ordem de 20 de abril de 1722: "que a terra que está devoluta entre os dous Governos se divida igualmente por distância imaginária lançada pelos rumos evitando as contendas entre os dous Governadores e Ouvidores Geraes" (Ottoni, 1960, p.20).

Até 1720, a Coroa tivera o cuidado de não deixar o controle do litoral sob jurisdição da Capitania de São Paulo e Minas do Ouro. 0 litoral pertencia à donataria de Itanhaém, que estava subordinada ao Rio de Janeiro. Esta precaução visava impedir o extravio do ouro, através dos portos marítimos. Quando feito o desmembramento das capitanias, o litoral ficou sob o controle da Capitania de São Paulo e houve extremo cuidado em fechar a Capitania de Minas Gerais com Registros e proceder o patrulhamento dos caminhos, a fim de obstar o extravio do ouro pelos portos do litoral (Ottoni, 1960, p. 21).

\footnotetext{
1 O Alvará Régio de 2 de Dezembro de 1720 determinava que a Capitania de São Paulo teria “[...] por Limites no sertão, pela parte que confina com o Governo de Minas, os mesmos confins que tem a Comarca da Ouvidoria de São Paulo, com a Comarca da Ouvidoria do Rio das Mortes" (APESP, 1986, p. 6).
} 
Ao longo das quatro primeiras décadas do século XVIII, esse imenso território, cuja administração e jurisdição cabia a São Paulo, foi duplamente ampliado com a descoberta de novas jazidas de ouro nas regiões de Mato Grosso (1719) e Goiás (1725), onde modestos arraiais de mineração logo foram elevados à condição de vila (Bueno, 2009, p.272). Tal processo culminaria, em 1748, com a criação das Capitanias de Goiás e Mato Grosso, no mesmo ano em que São Paulo perde sua autonomia administrativa, ficando seu governo subordinado ao governo do Rio de Janeiro.

A restauração da Capitania de São Paulo só aconteceu em 1765, motivada por questões geopolíticas. As instruções de governo, enviadas pelo Marquês de Pombal e dirigidas a Dom Luis Antonio de Sousa Botelho Mourão, governador da capitania (1765-1775), ordenavam a construção de uma estratégia de consolidação territorial, reafirmando a posse do interior do continente, frente aos espanhóis. A implantação dessa política colonizadora pretendia romper com o quadro de despovoamento do território paulista, e se deu através da inauguração da produção de açúcar voltada para o comércio metropolitano, articulada à produção de subsistência de uma rede de povoados, freguesias e vilas (Bellotto, 2007).

Os governadores paulistas buscaram, então, aprimorar estruturas que garantissem os fluxos de pessoas e mercadorias no território, bem como consolidar os limites com os domínios da Espanha e com as capitanias confinantes. Contudo, a ocupação das áreas de fronteira, entre as capitanias de São Paulo e de Minas Gerais, nunca foi consensual entre as autoridades, tanto metropolitanas quanto coloniais.

O litígio lindeiro entre São Paulo e Minas Gerais originou-se não só da divergência das autoridades civis, mas também das eclesiásticas, sobre os limites dos termos das vilas e das freguesias na região de fronteira, discussão que perdurou por anos, e cuja solução se institui apenas em 19372. As correspondências sobre o assunto são inúmeras e podem ser encontradas nos arquivos do Rio de Janeiro, da Cúria Metropolitana de São Paulo, da Câmara Municipal de São Paulo, no Arquivo do Estado de São Paulo, bem como no Arquivo Nacional (Souza, 2004, p. 156).

\section{A abertura dos caminhos entre as capitanias de São Paulo e Minas}

Nos dois primeiros séculos de colonização, embora a população tenha se fixado no litoral, os colonizadores iniciaram a penetração dos sertões, abrindo caminhos. As rotas foram definidas pelas condições do relevo e da hidrografia. Os grandes rios, como o São Francisco, o Amazonas e aqueles da bacia do Prata, foram utilizados para a penetração dos sertões. Na região objeto do nosso estudo, podemos ver a utilização dos rios Grande, Pardo e Sapucaí como elementos físicos que condicionaram a ocupação do território. Outros fatores que contribuíram para adentrar o sertão são as rotas indígenas milenares. Os paulistas desenvolveram um modo de vida que assimilou os conhecimentos dos índios, em relação às formas de penetração nos sertões. (Cruz, 2010, p. 15-6)

A região que corresponde hoje ao sul do estado de Minas Gerais, e que no século XVIII era o território da Comarca do Rio das Mortes, foi rota de penetração dos paulistas para a região dos descobertos auríferos. Eram quatro os caminhos utilizados pelos paulistas: 0 Caminho de Fernão Dias, o então chamado Caminho de São Paulo, ou Caminho Velho, o Caminho do Anhanguera e o Caminho dos Goianases. Ao longo destes caminhos formaram-se pousos, que deram origem a vários núcleos urbanos.

O caminho de Fernão Dias partia de São Paulo em direção a Atibaia, passava por Bragança Paulista e pelo registro de Jaguarí, na altura de Camanducaia, seguia ao norte passando pela serra de Araquamaba (atual Canguava), rio do Peixe, pelo topônimo Três Irmãos, pelo povoado de Mandu (atual Pouso Alegre) e rio homônimo e seguia até o povoado de Santana do Sapucaí (atual Silvanópolis). Dalí, em direção nordeste, transpunha-se o rio Sapucaí em local chamado passagem do Sapocaí (antiga grafia) chegando-se a São Gonçalo e depois a Campanha do Rio Verde. De Campanha seguia-se novamente em direção nordeste

\footnotetext{
${ }^{2}$ A Lei Federal no 375, de 7 de janeiro de 1937, sancionada pelo Presidente da República Dr. Getúlio Vargas, aprovou o convênio celebrado entre os estados de Minas Gerais e São Paulo, sobre seus limites (Ottoni, 1960,p.19).
} 
passando pelos rios São Bento, Verde (em local denominado Ponte do Rio Verde), do Peixe, Angaí, e Capivari, chegando-se ao local denominado Curralinho (não encontrada correspondência em mapas atuais), de onde se encontrava com o caminho Velho na passagem do Rio Grande (Cruz, 2010, p. 20).

Este não era o trajeto mais usado para se chegar de São Paulo às minas, contudo, ao longo de seu percurso, originam-se importantes núcleos urbanos que se destacam nos conflitos de limites em questão. 0 caminho mais usado pelos paulistas para acessar as minas era o Caminho Velho, que passava pelo vale do Rio Paraíba, onde já havia núcleos urbanos consolidados como Mogi das Cruzes, Jacareí, Taubaté, Pindamonhangaba e Guaratinguetá. A passagem pela garganta do Embaú constituía um trecho extremamente penoso desta rota (Morais, 2005, p.135).

O chamado caminho do Anhanguera, ou Caminho para Guaiases, foi aberto, em 1722, por Bartolomeu Bueno, o filho, seguindo a rota iniciada por seu pai. Partia de São Paulo e Santana do Parnaíba, seguindo trilhas indígenas, dirigia-se para Jundiaí. Desse ponto, seguia em direção ao norte, cruzando os rios Atibaia, Jaguari, na região em que, a partir de pousos, foi fundada a Vila de São Carlos (atual Campinas, SP). A partir desses pousos, o caminho cruzava os rios Mogi, Pardo e seguia em direção ao norte, até cruzar o Rio Grande, e daí ao local das minas de Goiás. A partir de Mogi Mirim (freguesia elevada a vila em 1769), este caminho desenvolvia variantes para as regiões de Jacuí e Cabo Verde, objeto de alguns dos litígios em questão.

O território ao longo do Caminho dos Goiases foi objeto de disputa territorial entre mineiros e paulistas, a partir do século XVIII. Até a abertura do caminho, este era um território desconhecido pelos colonizadores e a vila de Jundiaí, elevada em 1655, era então "boca de sertão", o que significa que dizer que toda a região estava sob sua jurisdição. Quando, em 1769, a freguesia de Mogi Mirim é elevada a vila, tendo o seu termo desmembrado da vila de Jundiaí, as disputas entre paulistas e mineiros passam a ser discutidas em território sob sua jurisdição.

0 quarto caminho relevante para o estudo da região onde acontecem alguns dos litígios em questão, era o Caminho dos Guaianases. Segundo Moraes, este era o caminho que mais possuía variações: saindo de São Paulo, passava pelo vale do Rio Mogi-Guaçú, e daí desenvolvia variantes passando por Cabo Verde e Jacuí (Moraes, 2006, p.138). Como demonstra a Figura 1, a análise da cartografia histórica indica diversas derivações do Caminho do Anhanguera, ou caminho dos Caminhos dos Goiases, que se encontravam com as variantes do Caminho dos Guaianases.

Durante o período colonial, a Coroa portuguesa buscou controlar todas as rotas de acesso à região das minas e evitar o descaminho do ouro. Para evitar o contrabando e garantir o controle do fisco, coíbe-se a abertura de novos caminhos para a região e, naqueles já existentes, estabeleceram-se as guardas e os postos de controle e tributação, os registros, como é possível verificar na Figura 1. Contudo, a política de controle por parte da Coroa não conseguiu evitar a abertura de picadas e caminhos secundários percorridos por aqueles que se aventuravam em burlar o fisco.

A análise da cartografia histórica também permite reconhecer que, além dos núcleos urbanos, representados por vilas, freguesias e capelas, e dos estabelecimentos de controle dos fluxos, na forma de guardas e registros, esses caminhos também eram pontuados por fazendas, que se valiam dessas rotas para o escoamento da sua produção, e por pousos que se estruturavam para abastecer os viajantes, de acordo com o ritmo dos deslocamentos. Portanto, ao longo dos principais caminhos, os fluxos de pessoas e mercadorias estruturam formas de ocupação em uma rede urbana hierarquizada.

Os litígios pelas fronteiras se instalam à medida que avança a ocupação dos confins das capitanias. Os paulistas que varrem os sertões, seguindo pelos principais caminhos e suas derivações, tomam posse de territórios em nome da autoridade de vilas da capitania de São Paulo e tais ações serão contestadas pelas autoridades mineiras. 


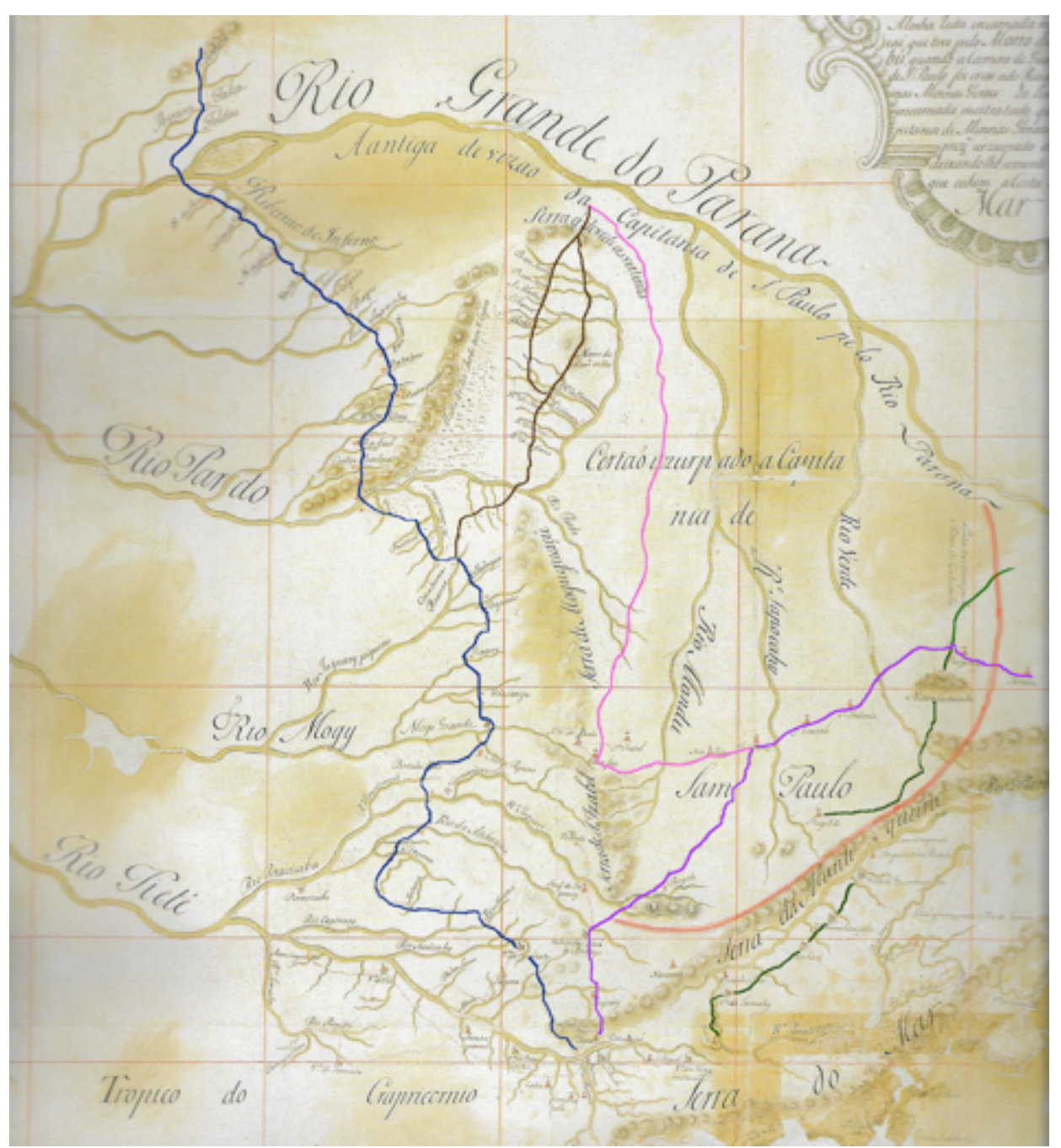

Figura 1. "Mapa da capitania de São Paulo em que se mostra tudo o que ela tinha antigamente the o Rio Paraná". Produzido por volta de 1773. Na legenda original do mapa lê-se: "A linha encarnada mostra a divisão que teve pelo Morro do Cachambu, quando a Camera de Guaratinguetá em São Paulo foi criar a do Rio das Mortes nas Minas Gerais. A linha encarnada mostra tudo quanto a Capitania de Minas Gerais tem usurpado à de São Paulo deixando lhe somente as terras que cahem a Costa do Mar". As autoras do artigo destacam, em verde, o "Caminho Velho"; em vermelho, o "Caminho de Fernão Dias"; em rosa, o "Caminho dos Guaianases" e suas variações e em azul, o "Caminho dos Goiases", com suas derivações em marrom. Desenho das autoras sobre o mapa original que se encontra no Arquivo Histórico Ultramarino. Fonte: Costa, 2007, p. 156.

\section{As divergências entre os limites das Comarcas e os termos das vilas}

Os primeiros conflitos relacionados aos limites do território paulista e mineiro se originam ainda no período em que estes faziam parte da mesma capitania, a de São Paulo e Minas do Ouro, criada em 1709. Para organizar a região das minas em relação ao poder civil, em 6 de abril de 1714, o governador da Capitania de São Paulo e Minas do Ouro, Dom Brás Baltazar, dividiu administrativamente o território mineiro em 3 comarcas: a Comarca do Rio das Velhas, a Comarca de Ouro Preto e a Comarca do Rio das Mortes, que tinham como sede, respectivamente, os Conselhos Municipais das Vilas de Sabará, Vila Rica e São João del-Rey. Até então, os demais termos ou vilas desta capitania estavam sob jurisdição da Comarca de São Paulo, criada para substituir a Ouvidoria Geral, por carta régia de 29 de outubro de 1700. A partir de 1714, a Capitania de São Paulo e Minas do Ouro fica então com 4 comarcas: São Paulo, Vila Rica, Rio das Velhas e Rio das Mortes. Só em 1720 é que a comarca do Rio das Velhas foi desmembrada para se criar a quinta comarca, a do Serro Frio, cuja sede era a Vila do Príncipe.

Em Portugal, a comarca era o território de jurisdição do corregedor, magistrado que tinha atribuições judiciárias, políticas e de "polícia". As comarcas criadas em Minas Gerais tiveram funções ainda mais 
amplas, pois também funcionavam como circunscrições fiscais. A criação das comarcas, maiores circunscrições civis na capitania, representam uma das primeiras concretizações de um projeto metropolitano para organizar a justiça e a cobrança de impostos, sem subdividir o vasto território das "minas de ouro" (Fonseca, 2011, p. 141-2).

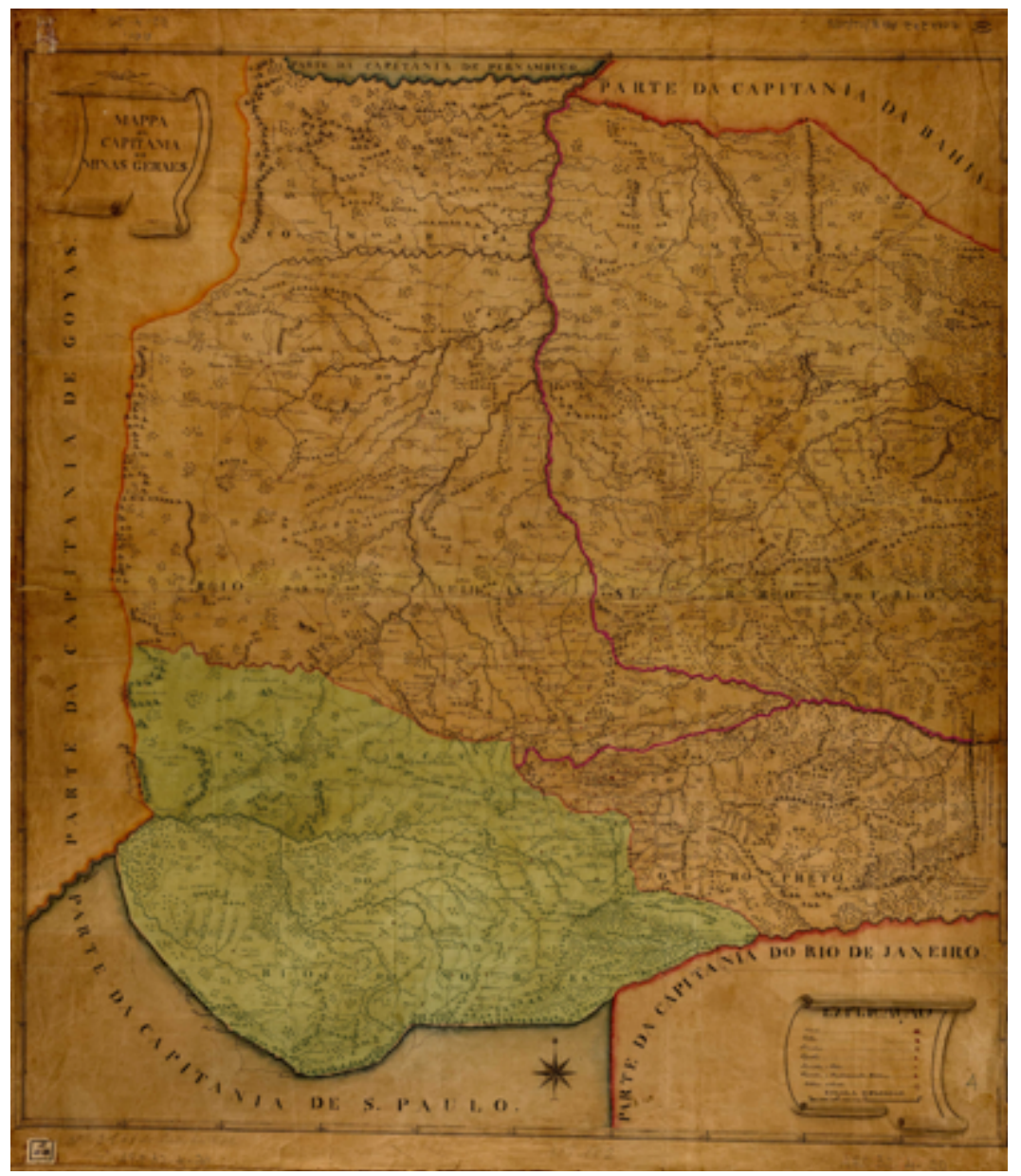

Figura 2. Demonstra os termos das quatro primeiras comarcas criadas no território mineiro, destacados pela linha vermelha. 0 território destacado pela cor verde corresponde à Comarca do Rio das Mortes. Os destaques foram sobrepostos pelas autoras sobre o mapa original de 1810 que apresenta os limites da então Capitania de Minas Gerais. Fonte: Biblioteca Nacional. Recuperado de: <http://objdigital.bn.br/objdigital2/acervo_digital/div_cartografia/ cart1017272/cart1017272.jpg>. Acesso em: setembro de 2016.

Os limites das comarcas eram definidos à medida que a colonização avançava. Importava, sobretudo, definir a qual comarca pertencia determinado núcleo minerador, para que não houvesse divergências em relação ao fisco. Como a definição de limites em sertões ainda por ocupar não era possível, foi estabelecida a condição que Fonseca denomina de "fronteira aberta", o que significa dizer que os contornos das Comarcas são definidos progressivamente, à medida que as terras iam sendo ocupadas (Fonseca, 2011, p.143). Os limites foram definidos com maior precisão nas zonas mais densamente ocupadas de interseção das circunscrições e coincidiam com os limites dos termos das vilas.

A Comarca do Rio das Mortes, território onde tem lugar os conflitos abordados neste trabalho, teve sua jurisdição demarcada, ao norte, pelos limites da vila de São João del Rei com as vilas de Sabará e Vila Rica e, ao sul e leste, pela Comarca de São Paulo, na divisa ainda imprecisa entre os termos das vilas de Santo Antônio de Guaratinguetá (1651), no vale do Rio Paraíba, e de São João Del Rei (1712), pela Serra da Mantiqueira (Ottoni, 1960, p.19). Nenhuma linha divisória ficou consignada pelos sertões à oeste, na bacia dos rios Grande e Paraná, ainda por desbravar.

A Câmara da vila de Santo Antônio de Guaratinguetá não se conformou com as divisas estabelecidas pela Serra da Mantiqueira, que afetavam seu termo e, em setembro de 1714, fincou o marco 
divisório no Morro do Caxambu, à meia distância entre ambas as vilas, sem a presença dos representantes da vila de São João del Rei3. Em revide, em 1727, representantes da câmara de São João del Rei quebram o marco e o transportam para o alto da serra da Mantiqueira, pela estrada que as ligava (Ottoni, 1960, p.19).

A vila de Guaratinguetá, fundada em 1651, no vale do rio Paraíba, território paulista, possuía no início do século XVIII um termo que fazia fronteira com a Capitania do Rio de Janeiro e com a Comarca do Rio das Mortes. Para compreender a abrangência territorial das vilas nesta região de conflito, no início do século XVIII, podemos observar o estudo do Instituto Geográfico e Cartográfico de São Paulo relativo ao território que hoje corresponde ao Estado de São Paulo. Neste território, a parte pertencente à Capitania de São Paulo, até 1700, abrangia 16 vilas. Dentre elas, seis vilas se localizavam no território de conflito, ou seja, na região de fronteira com a Capitania de Minas Gerais. No vale do Paraíba: Guaratingetá, Taubaté, Jacareí e Mogi das Cruzes, no eixo noroeste; e no sentido do caminho dos Guayases, São Paulo e Jundiaí (Figura 3).

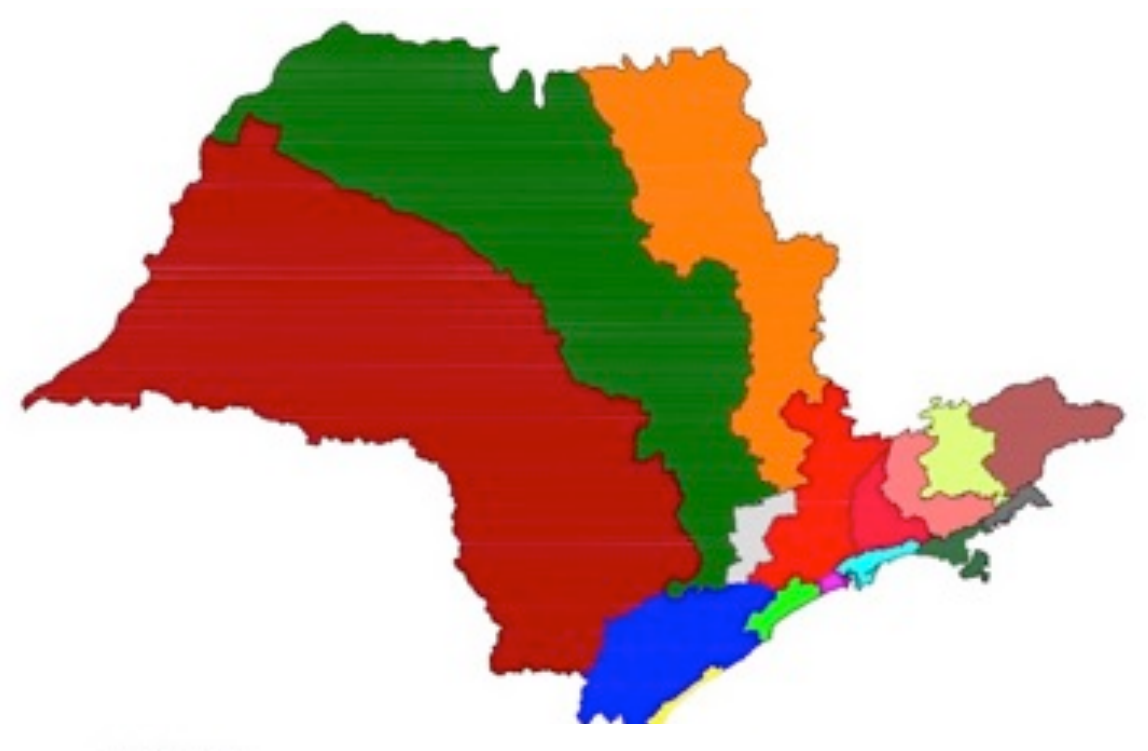

Até 1700

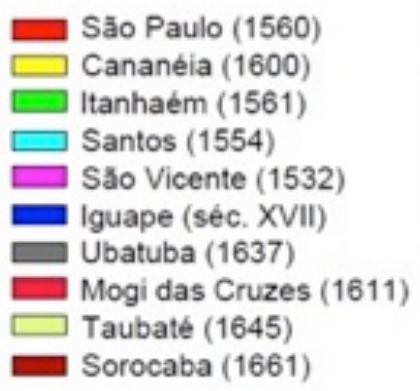

Embora as vilas de São João d'El Rei e Guaratinguetá ficassem a uma distância de quinze dias de viagem, a delimitação de fronteira imposta pelos mineiros deixava Guaratinguetá com cerca de cinco a seis léguas de território até a divisa. A vila paulista alegava que pessoas que cometiam crimes em seu território passavam com facilidade para a jurisdição da Comarca do Rio das Mortes, no extenso termo da vila de São João d'El Rei, ficando livres das justiças. Na carta do Governador de São Paulo ao de Minas, de 1731, a situação é explicitada:

[...] Ordena Sua Magestade se faça divisão entre esta capitania e esse governo, fazendo-se nova demarcação entre a vila de Guaratinguetá d'esta comarca, e o Rio das Mortes desse governo, por atalhar os grandes insultos que tem experimentado os moradores de Guaratinguetá e mais terras vizinhas, acometidos dos que vem do Rio das Mortes, fiados

\footnotetext{
${ }^{3}$ Auto de demarcação das Villas de Guaratinguetá e São João d’ El Rei, 1714 (APESP, 1986, p.5).
} 
em que as justiças d'este governo não podem seguir, nem entrar nas terras dessa jurisdição que estão desertas, [...] (APESP, 1896, p. 8).

Nos conflitos territoriais entre São Paulo e Minas, o território ao longo do Caminho dos Goyases, pertencente inicialmente ao termo da vila de Jundiaí, Comarca de São Paulo, também será objeto de disputa. A antiga freguesia de Nossa Senhora do Desterro de Jundiaí, fundada em 1651, no termo da Vila de Santana de Parnaíba, foi elevada a Vila de Nossa Senhora do Desterro de Jundiaí em 1655 pelo Conde de Monsanto, donatário da Capitania de São Vicente. No termo desta vila, uma antiga povoação, à margem direita do rio Mogi Guaçu foi elevada a freguesia de Mogi Guaçu em 1740, aproximadamente, ignorando-se a data precisa de sua formação. Ainda no termo da Vila de Jundiaí, no termo da freguesia de Mogi Guaçu, uma antiga povoação com o nome de Mogi dos Campos, em 1751, foi elevada a freguesia de São José de Mogi Mirim. Neste ano, portanto, a Vila de Jundiaí, passa a ser composta por três Freguesias, com seus respectivos termos delimitados: a freguesia da vila propriamente dita, a Freguesia de Mogi Guaçu e a nova Freguesia de Mogi Mirim. A recém-formada Freguesia de Mogi Mirim iria abranger nove léguas, isto é, do rio Atibaia até Mogi Guaçu. Dezoito anos depois, no dia 22 de outubro de 1769, a Freguesia de Mogi Mirim é elevada à condição de Vila. As nove léguas iniciais da Freguesia não representavam quase nada frente o imenso território que ficaria sob a tutela da Vila de Mogi Mirim. Seus limites compreendiam o Descoberto do Rio Pardo e toda área atravessada pela "Estrada dos Goyazes" (Chiachiri Filho, 1986, p. 23).

Em 1755, o auto de posse dos descobertos de ouro de Pedro Franco Quaresma, no sertão do Rio São João (atual região do município de Jacuí, SP), foi feito por autoridades paulistas: o procurador da Câmara da vila de Jundiaí, o representante do Ouvidor Geral e Corregedor da Comarca de São Paulo e o Intendente de ouro e Superintendente de terras minerais da Comarca de São Paulo (APESP, 1986, p. 63). Também em 1761, em região próxima, o auto de posse dos descobertos do Ribeirão de São Pedro de Alcântara e Almas é instituído pelo Alcaide da vila de Jundiaí, designado pelo Ouvidor Geral e Corregedor da Comarca de São Paulo (APESP, 1896, p. 70). Tais ações demonstram o empenho das autoridades civis da capitania de São Paulo para garantir a posse dos territórios cujo acesso se dava a partir de derivações do Caminho dos Goyases.

Além das questões que envolvem autoridades civis das Comarcas, as disputas de territórios entre as capitanias de Minas e São Paulo também devem ser entendidas no contexto das relações entre Igreja e Estado, entre altar e trono, relações estas que geraram conflitos entre as duas instituições, como fica evidenciado nos demais conflitos que serão tratados a seguir. Mas, antes de comentá-los faz-se necessário algumas considerações sobre a formação dos bispados de Mariana e de São Paulo em 1745 e dos litígios que envolvem suas circunscrições.

\section{A sobreposição entre a rede eclesiástica e a rede civil: litígios entre os territórios dos Bispados de Mariana e São Paulo}

Fundamentando-se na obra de Murillo Marx, Beatriz Piccolotto Siqueira Bueno esclarece a relação entre Igreja e Estado na formação da rede eclesiástica e da rede civil no Brasil colonial, quando a rede eclesiástica precedia a rede civil e, em termos jurídicos, ficava submetida a ela. A autora comenta a formação da rede eclesiástica num estudo sobre a formação das capitanias de São Vicente e Santo Amaro, que posteriormente seriam unidas para formar a Capitania de São Paulo:

Através da Igreja, de suas instâncias de base, umbilicalmente ligadas às do próprio Estado, a institucionalização de povoados dispersos dava-se, inicialmente, pela oficialização de sua ermida. A elevação de uma comunidade ao estatuto de capela curada significava a ascensão de uma região inóspita a núcleo reconhecido pela Igreja e também a garantia de visita de um pároco (cura). Tanto o acesso à assistência religiosa como o reconhecimento de fato e de direito perante a Igreja e o Estado motivavam a solicitação junto ao bispado. A subsequente elevação à condição de freguesia garantia o acesso ao batismo, ao casamento, ao amparo dos enfermos, aos sacramentos, aos registros de nascimento, de matrimônio, de óbito, com todas suas implicações jurídicas e sociais. Para além do acesso ao rito litúrgico, 
a elevação de uma capela a freguesia implicava em usufruto da formalidade civil (Bueno, 2009, p. 252).

Na formação da rede civil, a elevação da freguesia a vila revelava o anseio da autonomia política e administrativa do povoado, como explica Murillo Marx:

A sua aspiração seguinte seria constituir não mais um embrião oficial, a célula menor eclesiástica e administrativa, porém algo mais, que não se referia apenas ao tamanho ou à ascensão gradual hierárquica: seria alcançar a autonomia política e administrativa, seria passar a constituir sede de um município, passar a zelar por si mesma, aglomeração, e por um território próprio correspondente que lhe seria designado, seu termo. A autonomia municipal colocaria o povoado, quem sabe a antiga freguesia ou paróquia, como unidade autônoma dentro do Estado (Marx, 1991, p. 52).

A rede eclesiástica, formada por capelas, capelas curadas e freguesias se organizava territorialmente através dos Bispados nas suas Dioceses. A rede civil era formada pelas vilas e cidades e se organizava territorialmente pelas Comarcas, divisão administrativa das Capitanias.

Com relação à formação da rede eclesiástica, no território da Colônia, até 1551, todo o Brasil era hierarquicamente dependente da Diocese do Funchal (Ilha da Madeira), quando em 25 de fevereiro daquele ano foi erigida a Diocese de São Salvador da Bahia. Com a fundação da Prelazia do Rio de Janeiro em 1575, a então Vila do Rio de Janeiro ficou subordinada a esse novo ente, que se tornaria em 1676 a Diocese de São Sebastião do Rio de Janeiro (Figura 4).

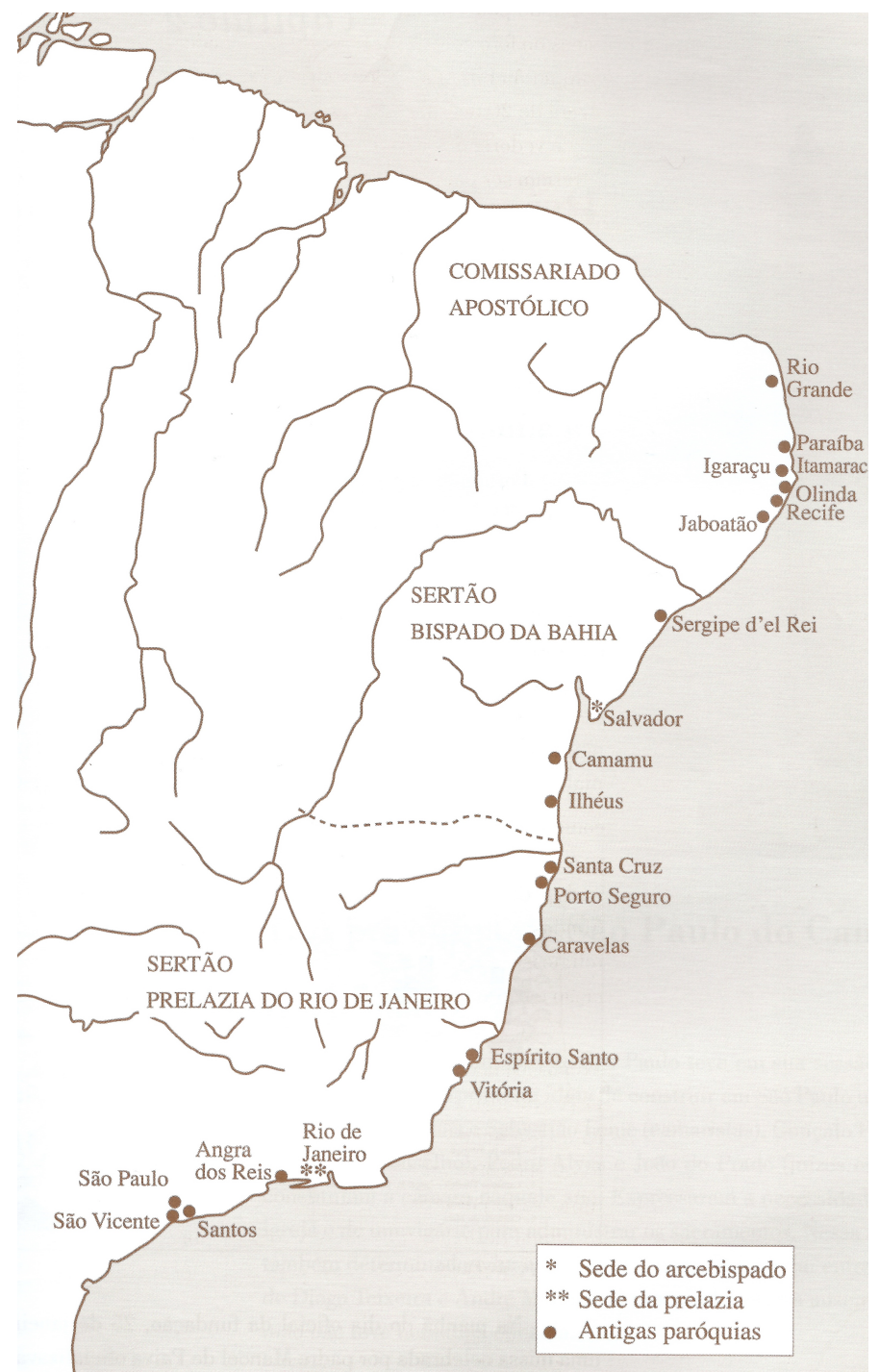

Até 1745 , a divisão eclesiástica da colônia era composta pelos seguintes territórios: o Arcebispado da Bahia, o Bispado de Pernambuco, o Bispado do Maranhão, o Bispado do Pará e o Bispado do Rio de Janeiro. Em 1745, Dom João V, rei de Portugal e dos Algarves, assina o decreto criando os bispados de São Paulo e Mariana e as prelazias de Cuiabá e Goiás. Todos estes territórios foram desmembrados da diocese do Rio de Janeiro (Figura 5), ficando parte deles pertencente à antiga diocese, do próprio Rio de Janeiro, outra parte a São Paulo e a terceira a Mariana. Estas duas últimas a constituírem-se dioceses com bispos e pastores próprios. A parte restante do território se bipartiria em duas prelazias: Goiás de Cuiabá (Figura 6).

Figura 4. 0 mapa demonstra a abrangência territorial do Arcebispado de São Salvador da Bahia, criado em 1551, com sede em Salvador (*); e da prelazia de São Sebastião do Rio de Janeiro, criada em 1575, com sede no Rio de Janeiro (**). 0 Arcebispado de São Salvador da Bahia possuía as seguintes paróquias: Rio Grande, Paraíba, Itamaracá, Igaraçu, Olinda, Recife, Jaboatão, Sergipe d'el Rei, Camanu e Ilhéus. A prelazia de São Sebastião do Rio de Janeiro possuía as paróquias de: Santa Cruz, Porto Seguro, Caravelas, Espírito Santo, Vitória, Angra dos Reis, São Paulo, Santos e São Vicente.

Fonte: Souza, 2004, p. 29. 


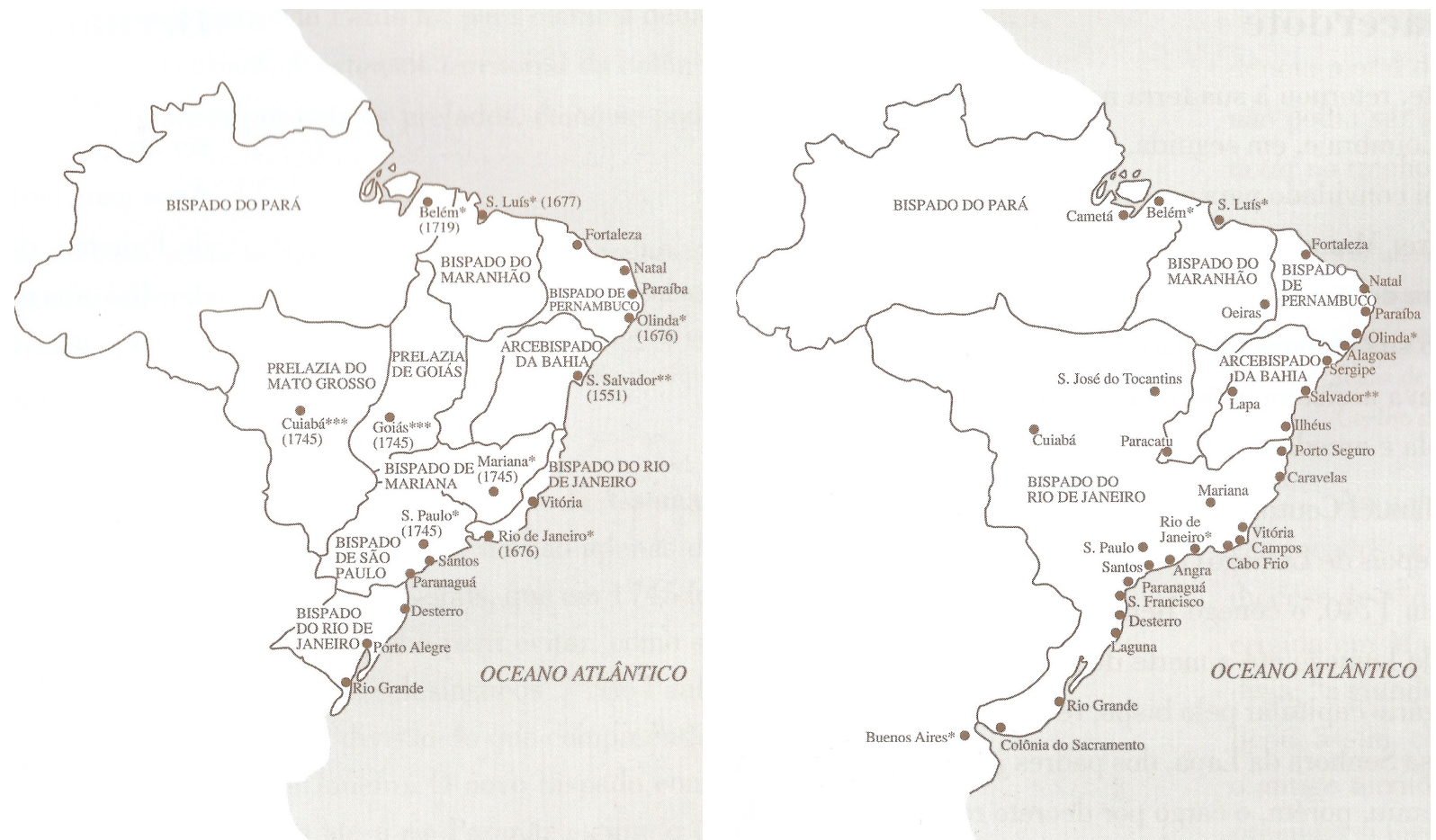

Figuras 5 e 6. À esquerda, a Figura 5 apresenta a divisão eclesiástica do Brasil, em 1745, antes da divisão do bispado do Rio de Janeiro. À direita, na Figura 6, a divisão eclesiástica do Brasil, em 1745, após a divisão do bispado do Rio de Janeiro com a criação dos bispados de Mariana e de São Paulo e as prelazias de Mato Grosso e Goiás.

Fonte: Souza, 2004, p.135.

O antigo bispado do Rio de Janeiro teria o limite pela parte austral com São Paulo, nas linhas seguidas pelas prefeituras seculares do Rio de Janeiro até o rio Paraíba. Daí seguindo o mesmo rio até o grande salto, onde, através de montes chamados Goitacás, desemboca. Daquele salto pelos cumes dos citados montes, limitar-se-ia com Mariana até atingir as linhas divisórias com o arcebispado de São Salvador, com o qual continuaria a ter o antigo limite.

Designou à segunda parte do bispado de São Paulo os seguintes limites: com o Rio de Janeiro, começando no rio Paraíba até outro rio Grande, chamado Paraná, onde continua com Mariana pelas linhas das prefeituras seculares de São Paulo, Rio de Janeiro e Minas Gerais. Pelo mesmo Rio Grande até onde se estende a posse do Rei de Portugal, ficaria pertencendo à prelazia de Goiás. A quarta parte constituiria a prelazia de Goiás e a quinta e última seria a prelazia de Cuiabá.

Em 22 de abril de 1745, D. João V assina o decreto criando os bispados de São Paulo e Mariana e as prelazias de Cuiabá e Goiás, comunica sua decisão à Roma e aguarda a sanção do Papa Bento XIV. As Dioceses de Mariana e São Paulo foram criadas em 6 de dezembro de 1745, pela Bula Candor Lucis Aeternae do Papa Bento XIV. No dia 23 de dezembro de 1745, foram expedidas as bulas e entregues ao comendador Manoel Pereira Sampaio, embaixador de Dom João V em Roma.

A Diocese de Mariana foi solenemente instalada em 17 de setembro de 1748, com a posse canônica do seu primeiro bispo, dom Frei Manoel da Cruz, cisterciense da família de São Bernardo. Já Dom Bernardo Rodrigues Nogueira teve sua nomeação régia para bispo da Diocese de São Paulo no dia 22 de abril de 1745, antes da ereção canônica da diocese, que aconteceu no dia 6 de dezembro de 1745. Chegou à vila de São Paulo em 1746.

Um dos primeiros problemas enfrentados por Dom Bernardo Rodrigues Nogueira, quando assumiu o bispado de São Paulo, foi relacionado aos limites das paróquias da nova diocese. No dia 28 de outubro de 1747, Dom Bernardo convocou os párocos para uma reunião na casa episcopal. Expôs o assunto e solicitou que todos os párocos fizessem o levantamento de suas freguesias, lançando no livro do tombo de cada paróquia seus limites, a lista de casais, fregueses menores e maiores. "Essa resolução do bispo encontrou uma forte oposição, principalmente dos párocos colados, que não admitiam remover em nada os limites sob seus domínios [...] Esse assunto se tornou polêmico na data de sua 
exposição aos párocos, ficando os limites das freguesias da Sé com Parnaíba e Mogi das Cruzes para serem resolvidos somente em janeiro de 1748" (Souza, 2004, p.153).

No tempo de Dom Bernardo Rodrigues Nogueira, a questão dos limites com os bispados de Mariana e Rio de Janeiro estava em aberto. Algumas correspondências foram sendo redigidas e envolveram até os governadores das capitanias. A questão era delicada, e cada um tentava fazer prevalecer seu ponto de vista. 0 bispo do Rio de Janeiro, Dom Frei Antonio do Desterro, reivindica seus limites ao assumir sua diocese, em $1^{\circ}$ de janeiro de 1747 (Souza, 2004, p.156).

Dom Bernardo já havia escrito ao Governador da Capitania de São Paulo, Dom Luis de Mascarenhas, explicando que a questão deveria ser tratada em Portugal e Roma para que pudessem dar uma decisão final e concluir juridicamente os limites para se dirimir as dúvidas de onde começava e acabava cada diocese em questão (Souza, 2004, p.156).

A carta do padre da freguesia de Campanha do Rio Verde, João Roiz de Amorim, ao Vigário da Comarca de Guaratinguetá, padre Gaspar de Souza Leal, de 10 de janeiro de 1747, revela a complexidade das divergências entre as circunscrições civis e eclesisásticas, com a tomada de posse de Pouso Alto, Baependi, Airuoca, Carrancas e Rio Verde, a mandado de Dom Bernardo, Bispo de São Paulo:

[...] correndo o tempo foi a Câmara de Guaratinguetá criar a do Rio das Mortes, formando um corpo de câmara. Chegando a Baependi, onde chamavam o Morro Caxambu, puseram um marco de pedra de que fizeram termo e assinaram; tudo se achará nesta vila de Guaratinguetá. Desta sorte ficaram alguns anos dominando aquele distrito até que o do Rio das Mortes como o mais poderoso e com aquelas fumaças que produz o ouro o foram quebrar. Puseram outro na Serra da Mantiqueira, à vista de Guaratinguetá, distante dez léguas, e daí para São João Del-Rei ou Rio das Mortes, quarenta. Esses camaristas, como pobres, assim ficaram por não poder em forças, e cabedais competir com aqueles. Veio governar São Paulo Antonio da Silva Caldeira, e vendo a sem razão das divisões alcançou ordem de Sua Magestade para dividir as duas capitanias pela demarcação antiga, ou pelo mesmo Rio Baependi, que fica próximo ao Caxambu e é caudaloso. Este vai fazer barra em outro que chama Rio Verde, mas como foi logo rendido assim ficou tudo sem haver quem disso se lembrasse, e não sei que caminho levou a ordem. Desta sorte não há divisão mais genuína que a do Rio Grande, porque sendo pelo Caxambu, ou pela Mantiqueira, havendo descobertas de ouro, se povoam os sertões, e havendo dúvidas em que altura fica por força se seguem condenadas em uma e outra jurisdição eclesiástica, o que se evita sendo a demarcação que Vmcê, me diz assim as bulas, e não outra. Pela Serra da Mantiqueira, correndo para o poente, se acham as minas de Itajubá, dominadas por São Paulo, e outras para o Norte, Sapucaí, Campanha do Rio Verde. Segue-se um grande vão de sertão entre estes e aquelas em que andam bandeiras de São Paulo até o mesmo Rio Grande, sertão que chega a Mogi Guaçu (APESP, 1896, p.186).

Os conflitos territoriais entre os bispados de São Paulo e Mariana, assim como entre os governos das capitanias de São Paulo e Minas, se ampliam na segunda metade do século XVIII e se referem às disputas relativas aos territórios das freguesias e das vilas, tanto nas jurisdições civis como eclesiásticas. As disputas em torno dos arraiais de Santana do Sapucaí, Ouro Fino, Cabo Verde, Itajubá e Pouso Alto revelam estes conflitos e serão tratados a seguir.

\section{Os descobertos de ouro e as disputas por freguesias na Comarca do Rio das Mortes e no Sertão do Rio Grande}

A posse dos descobertos de ouro implicou em disputas territoriais entre as Capitanias de Minas e São Paulo. Uma primeira contenda se dá quando chegam notícias ao Governador de Minas de que a região do Rio Verde estava sendo explorada por paulistas. Sob ordens do governo mineiro, o Ouvidor da Comarca do Rio das Mortes, Doutor José Antônio Callado, acorreu então à região para expulsar o paulista Capitão Bartolomeu Corrêa Bueno de Azevedo, morador da Freguesia de

${ }^{4} \mathrm{O}$ Governador foi substituído. 
São João do Atibaia, nomeado pelo Governador de São Paulo, Dom Luís de Mascarenhas (1739-1748), como Intendente e Guarda-Mór desses descobertos (Ottoni, 1960, p.22).

Acreditando haver jazidas abundantes na região do vale do Rio Sapucaí, onde se formariam as freguesias de Santana do Sapucaí e de Ouro Fino, paulistas adentraram este território. Dentre estes, tem-se noticias do sertanista Ângelo Batista, natural da vila de Pindamonhangaba [SP] e também do português Francisco Martins de Lustosa, proveniente da vila de Santiago de Lustosa, no Arcebispado de Braga, que residia na vila paulista de Santana das Cruzes do Mogi (atual Mogi das Cruzes, SP).

Em 1745, o descoberto de Santana do Sapucaí (atual Silvianópolis, MG), foi relatado por Lustosa ao governador de São Paulo, Dom Luís de Mascarenhas, que o nomeou Guarda-Mór das minas de Santana do Sapucaí e Ouro Fino, sob jurisdição da vila de Santana das Cruzes do Mogi, em 28 de setembro de 1746, apesar da resistência da Câmara de São João del Rei.

Acirraram-se então as disputas entre Gomes Freire de Andrade - que acumulava o Governo da Capitania de Minas (1735/1763) e do Rio de Janeiro (1733/1763) e Dom Luís de Mascarenhas, governador da Capitania de São Paulo (1739-1748), pelas divisas e posse das minas, contudo convinha à Metrópole que os descobertos nas divisas das duas capitanias ficassem sob a jurisdição de Minas, em virtude de suas fronteiras serem fechadas por registros e policiadas. Sem acesso direto aos portos marítimos a Capitania de Minas oferecia para as autoridades da Coroa maior garantia contra os descaminhos do ouro. Em consequência do conflito entre as autoridades mineiras e paulistas, a Metrópole ordenou que o governador Dom Luís de Mascarenhas retornasse a Portugal. A partir de então, a Capitania de São Paulo perde sua autonomia, passando a ficar subordinada ao Rio de Janeiro5. A Coroa concedeu então ao Governador Gomes Freire de Andrade plenos poderes para fixar as divisas com a Capitania de Minas pelos rios Grande e Sapucaí, ou por onde melhor lhe parecesse. Nessa oportunidade, também foram desmembradas de São Paulo as capitanias de Goiás e de Mato Grosso.

Gomes Freire de Andrade incumbiu o Ouvidor da Comarca do Rio das Mortes, Tomaz Rubby de Barros Barreto do Rêgo, de fixar as divisas entre as capitanias. Depois das diligências que julgou necessárias, Tomaz Rubby deslocou-se para Santana do Sapucaí, acompanhado de 18 pessoas, das quais 13 eram da vila de São João del Rei, e expediu o auto de demarcação das divisas, em 19 de setembro de 1749. As divisas foram então interpretadas como uma linha reta desde o Morro do Lopo, passando pela Serra de Mogi, até encontrar o Caminho dos Goyases, ou Caminho do Anahnaguera (Ottoni, 1960, p.26).

Criados os bispados de Mariana e de São Paulo, apressou-se o Bispo de São Paulo, Dom Bernardo Rodrigues Nogueira, logo após a sua posse, a criar a paróquia de Santana do Sapucaí, o que fez por provisão de 8 de janeiro de 1747, nomeando vigário o Padre Lino Estêves de Abreu. Mas, como em 1748, Dom Luís Mascarenhas retirou-se, com a extinção do governo da Capitania de São Paulo, Gomes Freire de Andrade, a partir de então Governador do Rio de Janeiro, Minas e São Paulo, tratou de fixar os limites das duas dioceses, o que fez sem violência.

Como a Bula Motu Proprio determinava que as divisas eclesiásticas dos bispados deveriam seguir os limites dos governos seculares, um requerimento do bispo de Mariana, dirigido a Tomaz Rubby, se refere à divisão dos bispados de São Paulo e Mariana, devendo ficar para este último os distritos de Santana do Sapucaí e Ouro Fino:

Diz João Bernardo da Costa Estrada como Procurador do Exmo. e Revmo. Sr. Bispo da Diocese de Mariana, que, como S. M. foi servido mandar dividir as capitanias de Minas Gerais e São Paulo, cuja divisão foi cometida a Vmcê como Ouvidor Geral e Corregedor da Comarca do Rio das Mortes, e como a divisa se estendesse da Serra da Mantiqueira até o Morro do Lopo e daqui correndo a encontrar com o Rio Grande, o que melhor consta da certidão do auto da divisão, e como o Motu-Proprio de S. Santidade declara que a divisão dos Bispados de Mariana e de São Paulo seja pelos limites dos governos seculares, estando

\footnotetext{
5 Por carta régia de 9 de maio de 1748, é extinto o governo da Capitania de São Paulo, subordinando-a aos Governadores e Capitães-gerais do Rio de Janeiro.
} 
a divisão feita como está, de posse tomada, quanto ao secular, pretende o suplicante que Vmcê. Iha dê tanto a este distrito de Santana do Sapucaí, como de São Francisco de Paula de Ouro Fino, como Procurador bastante do Exmo. e Revmo. Bispo de Mariana. P. a Vmcê. se sirva empossar ao suplicante na forma referida, visto a procuração junta. E. R. Vcê". E, com o despacho favorável do Ouvidor, foi lavrado o auto de posse de Santana do Sapucaí, a 20 de setembro de 1749, lavrado "nesta igreja matriz do arraial de Santana do Sapucaí (Barbosa, 1971, p. 500-501).

O termo de ratificação de posse das minas de Santana do Sapucaí, datado de 13 de julho de 1748, e praticado pelos oficiais da Câmara de Mogi das Cruzes, estendia a posse pelo Rio Mogi Guaçu, até o Rio Pardo (Ottoni, 1960, p.22). Neste mesmo ano, as autoridades do Rio das Mortes pretenderam tomar posse das minas, sendo repelidas por Lustosa. Mas, a transferência definitiva do território para a Capitania das Minas levou Lustosa a refugiar-se no sítio de Ouro Fino, onde permaneceu pouco tempo e fundou o arraial de Ouro Fino. A capela de São Francisco de Paula de Ouro Fino foi provida pelas autoridades diocesanas de São Paulo, em 8 de março de 1749. Essa elevação se deu por iniciativa do Bispado de São Paulo, que dava todo o apoio ao Guarda-Mor, no sentido de garantir também a posse civil para a Capitania de São Paulo. Porém, os limites entre as capitanias de Minas e São Paulo não estavam bem definidos e em setembro daquele mesmo ano, o rei de Portugal, D. João V, ordena que Ouro Fino passasse a pertencer à Capitania das Minas encaminhando esta solicitação ao seu governandor, Gomes Freire de Andrade. Temendo represálias da circunscrição civil, Lustosa mudou-se para a atual cidade de Curitiba [PR]. A freguesia de Ouro Fino ficou então subordinada ao bispado de São Paulo e sob jurisdição da vila de São João Del Rey. Em 1799, após a elevação da vila de Campanha, a freguesia de Ouro Fino passou a compor o termo dessa vila (ver subitem 6 do artigo e Figura 10). A freguesia foi elevada a vila somente em 22 de julho de 1868 (Barbosa, 1971, p. 328).

Os territórios de Cabo Verde, Itajubá e Pouso Alto também foram objeto de disputas entre paulistas e mineiros e estão na região de fronteira entre as duas capitanias no século XVIII. Cabo Verde, originalmente capela de Nossa Senhora do Rosário do Cabo Verde, originou-se pela penetração de bandeirantes paulistas que, em 1747, se fixaram na região com objetivo de extrair ouro. Há também registro de que foram os ilhéus de Cabo Verde os primeiros que ali se estabeleceram, em 1750 , dando origem ao nome do povoado. 0 trabalho de mineração também exigiu a vinda para as lavras de escravos negros, provavelmente originários do porto de Moçambique. Em 1766, a capela foi elevada a curato, pelo Bispado de São Paulo, com o nome de Arraial de Nossa Senhora da Assunção (Barbosa, 1971, p.89). Posteriormente, o território da Freguesia de Cabo Verde foi anexado ao termo da Vila de Campanha(ver subitem 6 do artigo e figura 10) configurando, portanto, a posse eclesiástica para o bispado de São Paulo e a posse civil para a Capitania de Minas.

Quanto às minas de Itajubá, tem-se que Antônio Caetano Pinto Coelho, um português natural da Província do Minho, que veio para o Brasil como Capitão-Mór da Capitania de Itanhaém, teria sido o descobridor das minas de Itajubá. (Cod. 346, Arquivo Público Mineiro). Entretanto, Geraldino Campista cita várias provas de que as minas de Itajubá foram descobertas por Miguel Garcia, o mesmo que andou perambulando por vários pontos das Minas Gerais. 0 auto de posse, para o Bispado de São Paulo, da Freguesia de Nossa Senhora de Soledade de Itajubá data de 8 de setembro de 1753. A freguesia, propriamente, seria criada por Dom Frei Antônio, Bispo de São Paulo, por provisão de 24 de novembro de 1762. Posteriormente, a Freguesia de Itajubá foi anexada ao termo da Vila de Campanha (Barbosa, 1971, p.205), configurando, assim como no caso de Ouro Fino e Cabo Verde, a posse eclesiástica para o bispado de São Paulo e a posse na circunscrição civil para a Capitania de Minas.

A origem do Arraial de Pouso Alto seria uma bandeira escravagista organizada por Antônio Delgado da Veiga, sertanista de São Paulo, e seu filho João da Veiga e Miguel Garcia que, saindo de Taubaté [SP], atravessaram a Mantiqueira e se embrenharam na região das Minas em busca de ouro. Em 1738, o povoado de Pouso Alto já possuía a sua Companhia de Ordenança. Este povoado foi elevado a freguesia, por ato do bispo de São Paulo, em 1748, com o título de Nossa Senhora da Conceição do Pouso Alto. Contudo, a freguesia foi confirmada e elevada a colativa, em 1752, conforme Livro de Lotação das Freguesias do Bispado de Mariana do Arquivo Eclesiástico de Mariana, ficando, portanto, em território do bispado mineiro. A partir de 1799, a freguesia de 
Pouso Alto passou a compor o termo da vila de Campanha (ver Figura 10) e foi elevada a vila, desmembrando-se de Baependi, em 19 de dezembro de 1878 (Barbosa, 1971, p. 383-384).

Mesmo com a perda da autonomia da Capitania de São Paulo, o avanço na ocupação dos sertões continua a ser feito por moradores provenientes de vilas paulistas, o que vai originar outros litígios. Apesar das demarcações estabelecidas pelas autoridades de Minas Gerais, o paulista Capitão Pedro Franco Quaresma desbravou, no ano de 1755, os sertões do Rio Grande. Chegou ao Rio Pardo, descobriu os rios da região do Desemboque: o Rio São João e seus afluentes, o São Pedro de Alcântara, das Almas, o ribeirão Santa Ana, e deu à região o nome de Cabeceiras do Rio Pardo, hoje região de Caconde.

Em 7 de outubro de 1755, a posse do sertão descoberto é instituida pelo Capitão Pedro Franco Quaresma na presença de autoridades paulistas, o procurador do Conselho da Vila de Jundiaí, a cujo termo a região ficou pertencendo, e o representante da Comarca de São Paulo. Em relação ao poder eclesiástico, tomou posse, em 1761, o Padre Marcos Freire de Camargo, que devia obediência ao vigário encomendado de Mogi Guaçu, designado pelo Bispado de São Paulo (Ottoni, 1960, p.28). Logo após assumir o governo da Capitania de Minas, Dom Luis Diogo Lobo da Silva (1763-1768) se empenha em implantar sua suserania na região do Desemboque, então termo da Vila de Jundiaí, Comarca de São Paulo. Com esse objetivo, realizou extensa viagem, em cuja comitiva estava o Secretário de Governo Claudio Manoel da Costa, que fez um relato detalhado da expedição ${ }^{6}$. A viagem tinha por finalidade a tomada de posse das minas, a extinção dos quilombos, a abertura de caminho que estabelecesse comunicação direta entre a vila de São João del Rei, onde se achava a Casa de Fundição, e as minas de Jacuí, estabelecendo registros de modo a evitar o descaminho do ouro para São Paulo (Ottoni, 1960, p.29). A fim de justificar a posse que havia feito, estendendo o território da Capitania de Minas pelo Desemboque, Dom Luis Diogo mandou organizar uma carta geográfica contendo o roteiro que realizara (Figura 7), e a enviou, juntamente com a remessa do quinto do ouro, ao Vice-Rei Conde da Cunha. Este, por sua vez, a remeteu a Lisboa, em carta de 13 de outubro de 1765 (Ottoni, 1960, p.38).

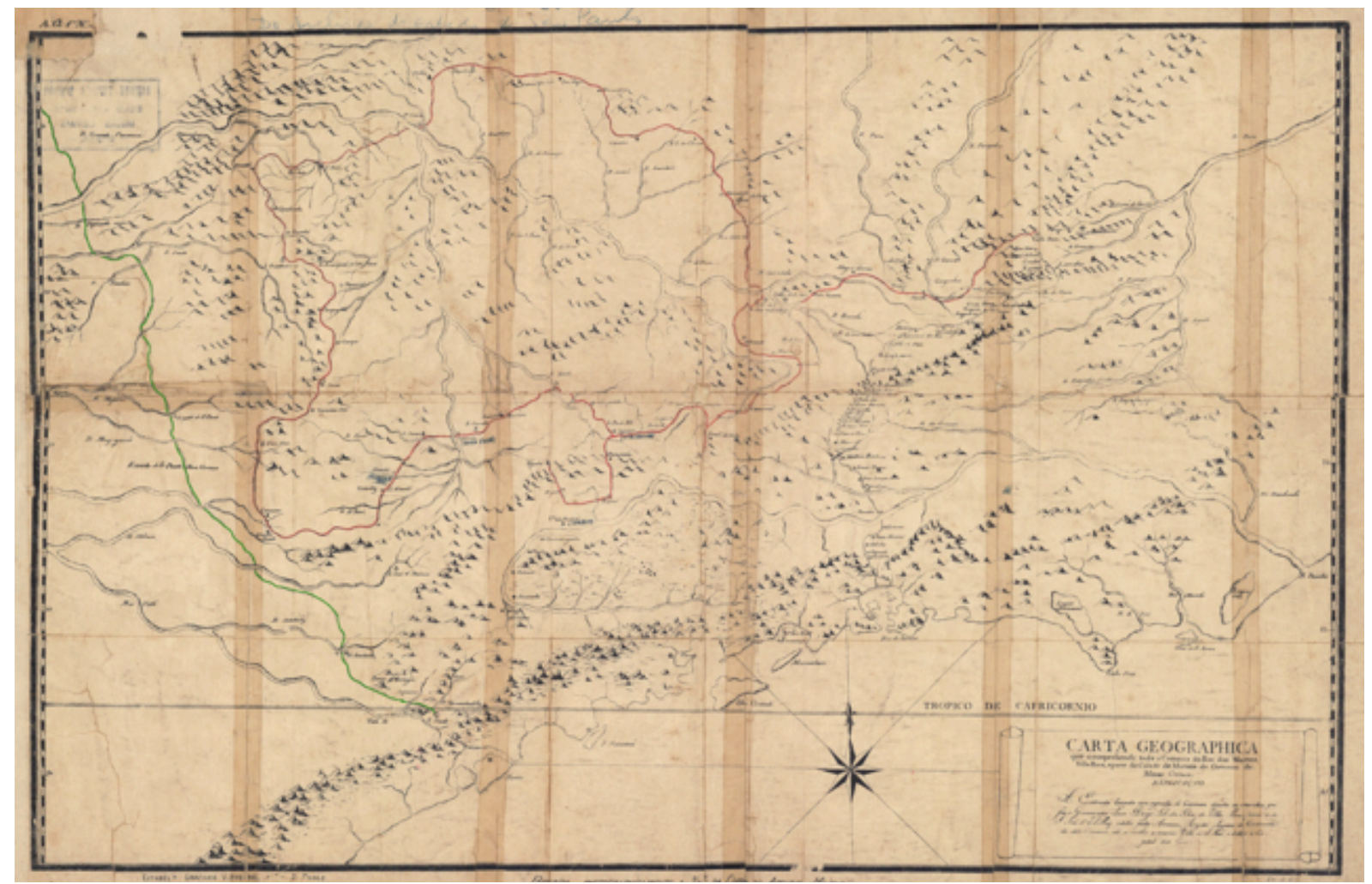

Figura 7. Carta Geographica que comprehende toda a Comarca do Rio das Mortes, Villa Rica e parte da Cidade de Mariana do Governo de Minas Geraes. Cópia da Comissão Geográfica de limites, 1827-1895 (data incerta). Em vermelho a rota da viagem de Dom Luis Diogo Lobo da Silva em 1765 e em verde, destacado pelas autoras, a estrada de São Paulo para Goiás. Fonte: Arquivo Público Mineiro.

6 O relato de Claudio Manoel da Costa que tem por título Assento do governador de Minas Gerais sobre a posse de Jacuí 1764. (APESP, 1896, p.77). 
Por volta de 1765, paulistas e mineiros exploravam as minas da região do Desemboque. 0 comandante do Registro de Itupeva, sargento Jerônimo Dias Ribeiro, informou ao Governador de São Paulo sobre a descoberta do mineiro Manoel Velho, que estava sendo ocultada. Porém, durante sua viagem à região, Dom Luis Diogo destituiu o posto do sargento Jerônimo Dias Ribeiro, comandante do arraial de Jacuí por parte de São Paulo, e transferiu o comando do Registro de Itupeva para as autoridades mineiras.

Seguindo as determinações do Marques de Pombal, Dom Luis de Sousa Botelho Mourão, Governador (1765-1775) da então restituída Capitania de São Paulo, tinha por objetivo implantar uma política de consolidação da ocupação do território paulista e de fomentar as atividades agrícolas. As ordens vindas de Lisboa determinavam a interdição de minas de ouro na Capitania de São Paulo. Quando, em 1765, Dom Luis Antonio de Sousa Botelho de Mourão chegou à Capitania de São Paulo para governa-la, recebeu uma correspondência do Governador de Santos, com um relato histórico das disputas entre mineiros e paulistas sobre a delimitação dos territórios mineiros.

Na carta do Governador de Santos, Alexandre Luiz de Souza Menezes, ao Capitão General de São Paulo, Dom Luiz Antonio de Souza Botelho de Mourão, datada de 5 de agosto de1765, Menezes comenta que, quando foram descobertas as minas de Campanha do Rio Verde por "nacionais desta Capitania de São Paulo", o governador e capitão general da Capitania de São Paulo naquela época, D. Luiz Mascarenhas, mandara o guarda-mór Bartholomeu Correa Bueno de Azevedo como regente das ditas minas. Quando este chegou a elas, o ouvidor da Comarca do Rio das Mortes, Cypriano Jose da Rocha, lá se achava com um grande número de "povo", impedindo o ingresso ao dito Bartholomeu Correa Bueno. Assim "ficou este sem administrar ato algum de sua jurisdição, por não ser causa de huma alteração de Armas, entre hum e outro partido e aly faz o dito Ministro [...] autos de divisão pelo Rio Sapucay que ficou sendo rayaentrhuma e outra Capitania". Segundo Menezes, esta divisão pelo Rio Sapucay se conservou até o ano de 1749, quando o Doutor Thomas Rubby de Barros, por comissão do Exmo. Sr.Conde de Bobadella, Gomes Freire de Andrade, General que foi destas Capitanias (Rio de Janeiro, Minas e São Paulo), alterou esta divisão fazendo outra "muito por aquém do dito Rio Sapocahy, de sorte que ficarão para a Capitania das Geraes as minas de Ouro Fino e Santa Anna que se achavam no districto de São Paulo" (APESP, 1896, p. 98).

Ainda segundo o relato de Menezes, em 1761, as novas minas "vulgarmente chamadas Dezemboque", que compreendiam os Arrayaes de Santa Anna, São Pedro de Alcântara, São João do Jacuhy e Asumpção de Caboverde, "tendo desta Cidade passado ao dito Desemboque o Doutor Ouvidor desta Comarca, João de Souza Filgueiras, e feitos autos de posse naquelas minas, deixando em sua ausência quem administrasse justiça aos Povos e depois dele seu sucessor, o Dr. Domingos João Viegas, que fez eleição, e dos Juizes Ordinários." Porem, segundo Menezes, tudo isto ficara abandonado no ano de 1764, quando D. Luiz Diogo Lobo, Governador e Capitão General das Geraes "correndo aquelles Certões desde as Campanhas do Cabo Verde, Rio Claro, São João do Sapocahy, vulgo Dezemboque", fez uma divisão, por própria resolução, ficando para a capitania das Gerais todas as minas dentro da dita nova divisão com total exclusão da Capitania de São Paulo, "de tal sorte que athé as Igrejas de que se achava de posse na forma do motu próprio deste Bispado, ficarão expoliadas e providas pelo bispo de Mariana, e athé agora asim existem" (APESP, 1896, pp. 97-98).

Informava ainda Menezes que:

[...] agora se descobrirão minas de ouro [...] nas cabeceiras ou vertentes do Rio Pardo, que banha a estrada que desta Cidade (Santos) segue para Goyas, [...] e por ficarem as taes minas dentro da linha Devidente que deixou por balliza o bando do Exm. General das Geraes, se tem tomado posse por aquela Capitania (Gerais) deste novo descuberto com futuro prejuízo do Real Erário, sendo certo que o Ouro extrahido nelas deve vir buscar a Intendencia desta Cidade para com guia ir pagar o Real quinto do Rio de Janeiro, como se pratica (APESP, 1896, p. 98).

Durante a sua gestão, Dom Luiz Antonio de Souza Botelho de Mourão (1765-1775), empreendeu esforços para garantir para a Capitania de São Paulo parte do território com descobertos mineiros. Várias são as correspondências entre Dom Luiz Antonio de Souza Botelho de Mourão e seus subordinados sobre o assunto. Dentre estas, há ordens para arregimentar pessoas nas freguesias 
de Mogi Guaçu e Mogi Mirim e defender os descobertos. 0 governador troca correspondência com o Capitão Ignácio da Silva Costa. Este, em uma de suas correspondências, avisa ao governador que seria preciso fazer registro na Câmara de Jundiaí destes descobertos. Estes documentos revelam que parte do território em litígio com Minas pertencia ao termo da Vila de Jundiaí, especificamente, aos termos de suas freguesias Mogi Mirim e Mogi Guaçu.

Numa correspondência do comandante do Registro de Itapeva, sargento Gerônimo Dias Ribeiro, ao Governador de Santos, Alexandre Luiz de Souza Menezes, datada de 20 de agosto de 1765, o dito comandante comenta que chegara a este registro vindo do "descoberto do Dezemboque", onde estivera por dez dias para "segurar e cobrar os rendimentos das entradas deste Registro". Ele ainda comunica que, chegando ao Desemboque soubera de novidades sobre um novo descoberto nas vertentes, ou cabeceiras do Rio Pardo, na então Comarca de São Paulo (APESP, 1896, p. 86).

Outra correspondência do Capitão do Registro de Itapeva, Ignacio da Silva Costa, ao Governador de São Paulo, Dom Luiz Antonio de Souza, datada de 15 de setembro de 1765, revela as dificuldades de controle dos novos descobertos do Rio Pardo por falta de "bestas para levar os mantimentos" e comunica que ele havia escrito ao Capitão Manoel Roiz de Araujo Belem, morador da freguesia de Mogyguassú, para que "enviasse cinco ou seis homens fortes para desembaraçarem os caminhos e fazerem alguma ponte". (APESP, 1896, p.88)

Outra correspondência do Capitão Ignacio da Silva Costa, ao Governador de São Paulo, Dom Luiz Antonio de Souza Botelho de Mourão, de outubro de 1765, também escrita no novo Descoberto de Nossa Senhora da Conceyção do Rio Pardo comunicava que havia chegado ali no dia anterior e que no lugar não se encontrava roceiro que lhe pudesse assistir com farinhas e mais mantimentos, portanto havia ordenado ao sargento Geronymo Dias que os mandasse do Registro de Itapeva. O capitão comunicava ainda que, se fazia necessário registrar na Câmara da Vila de Jundiaí "o trabalho que se fez desta posse, para a todo tempo constar que com assistência daqueles cameristas" (APESP, 1896, p. 89).

Em correspondência de Santos, datada de 28 de Janeiro de 1766, o mesmo Governador da Capitania de São Paulo ordenava a Ignácio Cabral da Cunha que passasse nas freguesias de Mogyguassu e Mogymirim e nelas anotasse e notificasse todos os capitães de mato e demais pessoas desimpedidas de que necessitasse para que pudessem ir endireitar a picada que saia do Descoberto de Nossa Senhora da Conceição do Rio Pardo para o Registro de Itapeva (APESP, 1896, p.97).

Não tardou que as notícias da ocupação paulista chegassem ao governador de Minas Gerais, Dom Luis Diogo, que por sua vez envia uma carta a Dom Luis Antonio de Souza Botelho de Mourão, questionando suas ações. Diante disso, em resposta, o governador de São Paulo expressa sua posição de aguardar as decisões do Vice-Rei em relação à posse dos descobertos do Rio Pardo. Enquanto a decisão não é tomada, defende que cada um respeite a posse do outro, pelo critério de uti possidetis.

Dom Luis Diogo não estava sujeito às instruções do Marques de Pombal relacionadas à interdição das minas, medida só aplicável à Capitania de São Paulo. Empenhava-se o governador de São Paulo em fixar roceiros na região litigiosa, dando preferência aos moradores da sua Capitania e enquanto não era dada solução ao litigio das fronteiras, dava continuidade à sua politica de fortalecimento do controle do território, elevando a freguesia de São José de Mogi Mirim à categoria de vila, em 22 de outubro de 1769, desmembrada de Jundiaí. 0 termo da vila de Mogi Mirim estendeu-se segundo o Caminho dos Goiases desde o Rio Jaguari até o Rio Grande. Passaram a pertencer ao seu termo todos aqueles sertões, inclusive o Descoberto do Rio Pardo, até então integrantes do termo da Vila de Jundiaí, bem como a Freguesia de Mogi Guaçu.

O mapa elaborado pela Comissão Geográfica, em 1874 (Figura 9), compara as diversas linhas de divisa entre as Capitanias e depois Províncias de São Paulo e Minas Gerais, nos três momentos distintos analisados no presente artigo. A linha amarela demonstra a divisão feita pelo Ouvidor da Comarca do Rio das Mortes, Tomaz Rubby de Barros Barreto do Rêgo durante o governo de Gomes Freire de Andrade em 1749. A linha vermelha demonstra o assento de 12 de outubro de 1765, durante o governo do Vice Rei Conde da Cunha, atendendo a carta de ofício do Ministro e Secretário de Estado Francisco Xavier de Mendonça Furtado de 4 de fevereiro de 1765, quando a divisão entre as capitanias retornou aos limites pelo Rio Sapucaí, como no período anterior a 
1749, e coincidia com a divisão eclesiástica dos bispados de Mariana e São Paulo. A linha azul demonstra a divisão pelo Rio Pardo, válida em 1874, quando o mapa foi elaborado pela Comissão Geográfica.

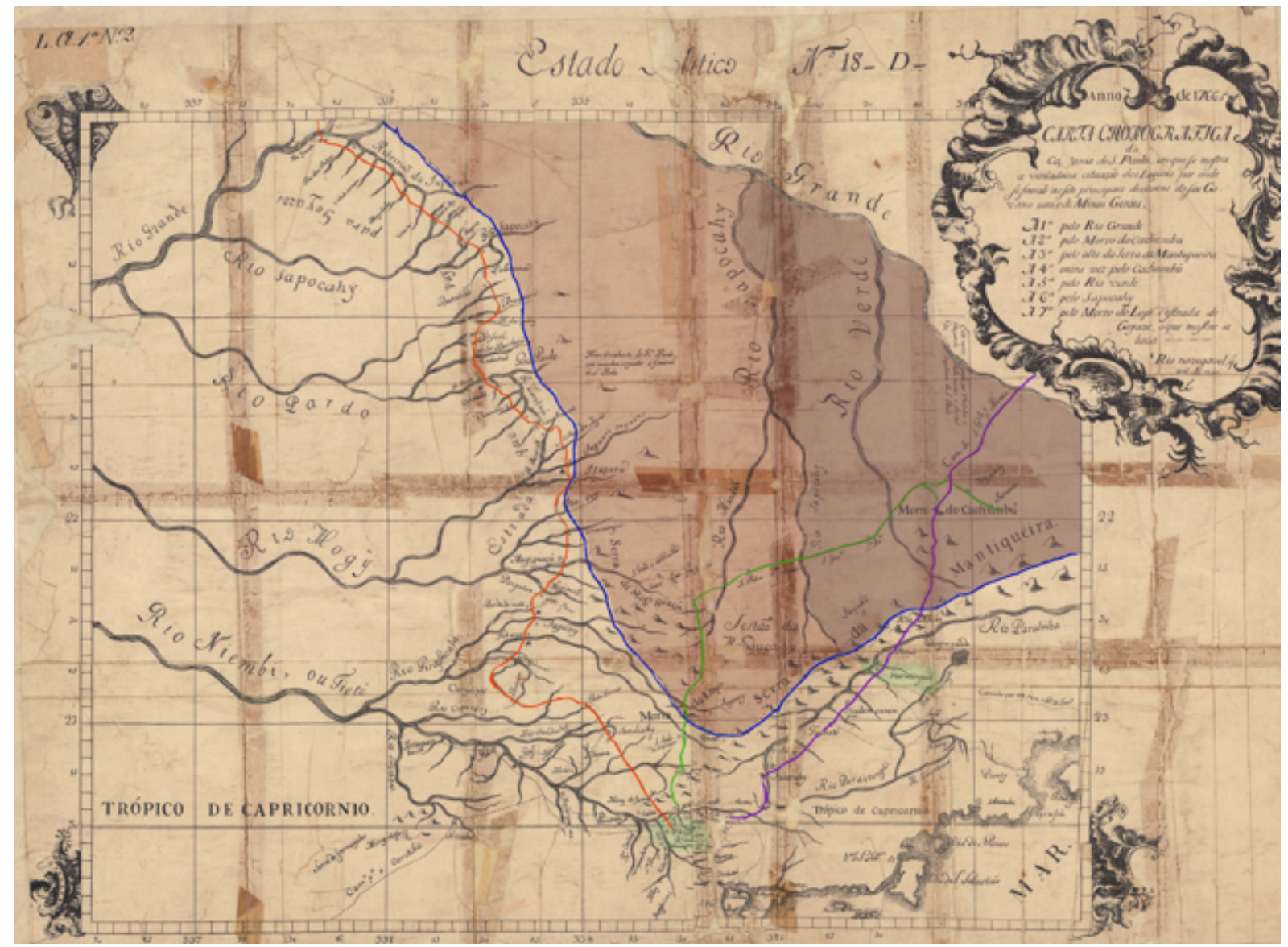

Figura 8. "Carta Chorographica da Capitania de São Paulo em que mostra a verdadeira cituação do Logares por onde se fizeram as sete principaes divizoens do seu governo com o de Minas Geraes, 1766". A legenda original lista: "A primeira, pelo Rio Grande, a segunda pelo Morro do Cachambu, a terceira pelo alto da Serra da Mantiqueira, a quarta outra vez pelo Cachambu, a quinta pelo Rio Verde, a sexta pelo Rio Sapucay e a sétima pelo Morro do Lopo e Estrada de Goiazes". No mapa original estes pontos são unidos por uma linha tracejada que as autoras do artigo destacam na cor azul. Outros destaques feitos pelas autoras são: a "Estrada de Goiazes" em vermelho, o Caminho de Fernão Dias em verde e o Caminho "Velho" em roxo; a cidade de São Paulo e a vila de Guaratinguetá, marcadas em verde. O limite entre os bispados de São Paulo e Mariana era então o Rio Sapucay. 0 território sob jurisdição civil da Capitania de Minas, mas subordinado ao Bispado de São Paulo é destacado em rosa claro e o território sob jurisdição civil da Capitania de Minas e subordinado ao Bispado de Mariana é destacado em rosa escuro.

\section{A formação da Vila de Campanha da Princesa, na Comarca do Rio das Mortes (1798) e as disputas com a Vila de Bragança Paulista}

A origem da Vila de Campanha da Princesa remete a 1737, quando em Vila Rica, começaram a chegar notícias sobre as "minas do Rio Verde", no sul da Capitania de Minas Gerais, na região entre o Rio Verde e o Rio Sapucahy. De imediato, o então Governador da Capitania de Minas Gerais, Martinho de Mendonça de Pina e de Proença, designou que o Ouvidor da Comarca do Rio das Mortes, Cypriano José da Rocha partisse em missão de reconhecimento e tomada de posse destes territórios das "minas do Rio Verde". 0 ouvidor partiu da vila São João del Rey em 23 de setembro de 1737 e fez sua entrada nas "minas do Rio Verde" em 2 de outubro do mesmo ano, quando providenciou a fundação de um arraial, denominado inicialmente de São Cipriano. Para tal, mandou fazer um rancho para si e ordenou que os demais que o acompanhavam fizessem o mesmo naquele sitio, assim como abrissem ruas, praça e dessem início à construção de uma capela. Segundo o ouvidor, seria preciso "mandar Sua Magestade fazer Villa, e por isso dei forma ao arraial, para que não sucedesse irregularidade que se acha nas villas de Minas". Este traçado 
inicial, segundo o ouvidor, estava fundado, com "praça e ruas em bôa ordem e muito bôas casas e ficava-se entendendo em fazer Igreja" (Valladão, 1937, p. 31-34).

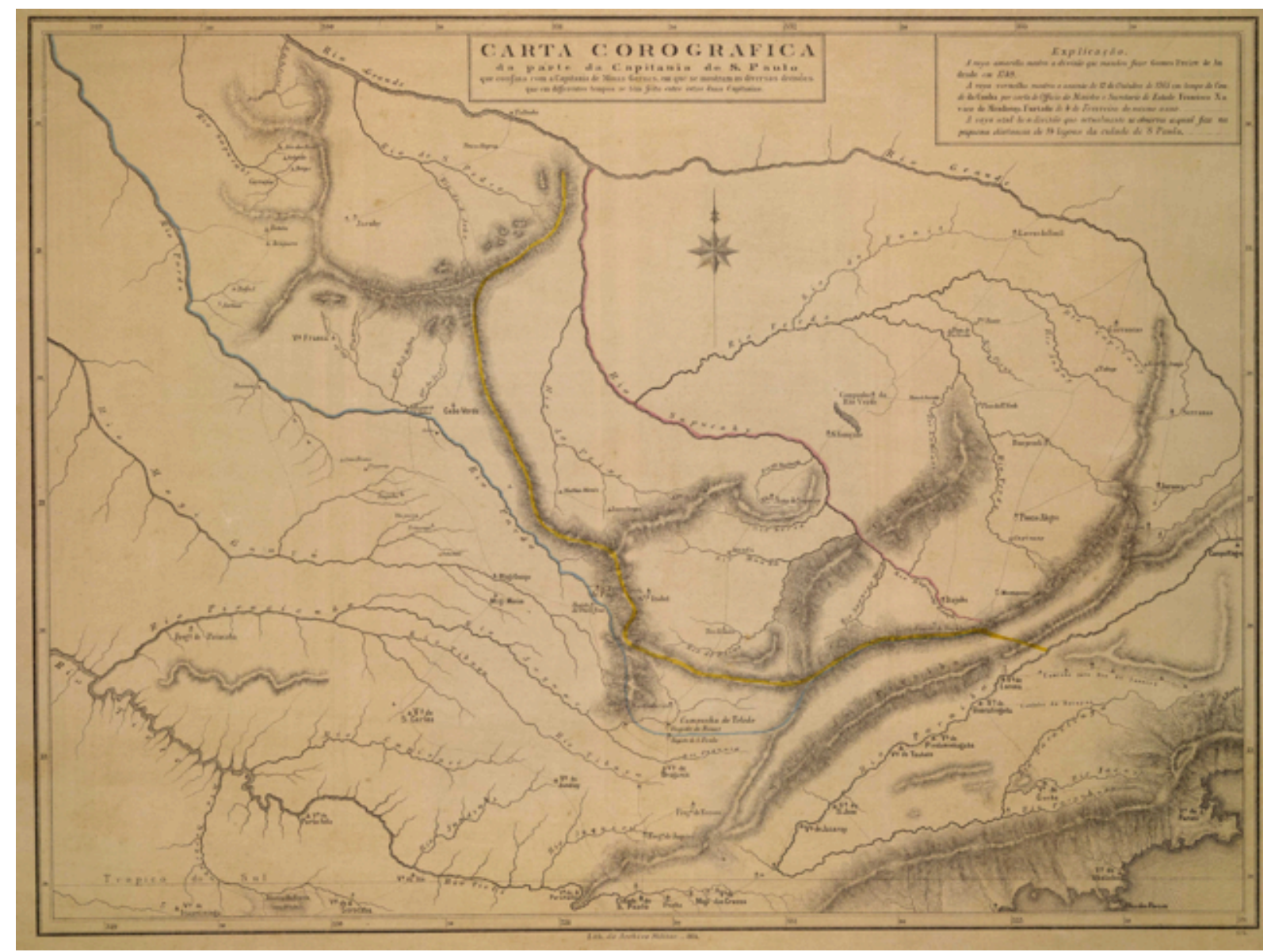

Figura 9. Carta Corográfica da parte da Capitania e São Paulo que confina com a Capitania de Minas Gerais, em que se mostram as diversas divisões que em diferentes tempos se tem feito entre estas duas capitanias.

Fonte: Elaborada pela Comissão Geográfica em 1874. Biblioteca Nacional.

Este arraial, pertencente ao termo da Vila de São João del Rei, passou a ser denominado Arraial de Campanha do Rio Verde e, em 1741, no contexto dos conflitos pelo controle e posse da região das Minas do Rio Verde entre paulistas e representantes legais da Comarca do Rio das Mortes, foi elevado a freguesia pelo bispado do Rio de Janeiro, com o nome de freguesia de Santo Antônio do Vale da Piedade da Campanha do Rio Verde. Em função de seu crescimento e prosperidade, em 6 de fevereiro de 1752 foi elevada à freguesia colativa, pelo bispado de Mariana.

Segundo Araújo, no final do século XVIII, os mais influentes moradores desta freguesia de "Campanha do Rio de Verde" passam a reivindicar a elevação da freguesia ao estatuto de vila através de petição encaminhada à rainha D. Maria I, quando solicitam o desmembramento de seu território do termo da Vila de São João del Rei (Araújo, 2008, p.111-114).

Em resposta, uma Ordem Régia de 20 de setembro de 1795, mandava que o governador da capitania prestasse informação sobre este pleito. 0 governador demandou informações à Câmara de São João dei Rei e ao Ouvidor da Comarca. Como a Câmara de São João del Rei ainda se ressentisse das perdas relacionadas aos desmembramentos das vilas de Queluz, Tamanduá e Barbacena, apresentou protestos contra este projeto. Alegavam os membros da Câmara de São João del Rei que não havia gente qualificada para exercer os cargos da República em Campanha e que a população seria composta apenas de mulatos, escravos e mestiços. Alegavam ainda que não havia igreja decente no lugar e que todo o ouro da região era extraviado (Valladão, 1937, p. 147-152).

A região requerida pelos moradores de Campanha, para compor seu termo, abrangia dez freguesias, cinco delas pertencendo ao bispado de São Paulo (Santana do Sapucaí, Camanducaia, Ouro 
Fino, Itajubá, Cabo Verde e Jacuí) e as outras cinco, pertencendo ao bispado de Mariana (além da própria freguesia de Campanha, Lavras do Funil, Baependi, Pouso Alto e Itajubá). A Câmara da Vila de São João del Rei se opunha a este projeto, pois ele significava a perda de uma vasta parte de seu território e também a diminuição de receita. Nesta disputa, foi feita a anexação de freguesias que haviam sido fundadas pelo bispado de São Paulo.

Por alvará de 20 de outubro de 1798, D. Maria I concede o título de vila à freguesia, apesar dos protestos da Câmara de São João Del Rei, nomeando-a "Vila da Campanha da Princesa". A demarcação do termo da vila foi prevista neste alvará de 1798 e no auto de declaração de criação da vila de 1799. No dia 23 de dezembro de 1799, o Juiz de Fora nomeado pela Rainha faz a leitura do Alvará de criação da vila e erige o pelourinho na praça da vila, defronte a casa Real de Intendência. A eleição da Câmara se fez em 27 de dezembro de 1799.

Na súplica à Rainha pela ereção da vila, os moradores de Campanha foram precisos em relação à sua delimitação. Contudo, o Alvará que a criou a vila foi impreciso em relação aos limites do seu Termo e se fazia necessário ainda sua demarcação. A demarcação deveria ser feita com a aprovação do Governador e Capitão General e seria "de forma que, em benefício público, compreendesse os lugares que ficam mais próximos à mesma Vila, do que as outras confinantes, que para este fim serão ouvidas" (Valladão, 1937, p. 188).

O mapa apresentado na Figura 10 foi elaborado para acompanhar o pedido de emancipação da Vila de Campanha da Princesa junto à Corte portuguesa. A representação não obedece às convenções cartográficas com relação a orientação do Norte ou o respeito a escalas. 0 mapa procura representar o termo pleiteado pela nova vila como um território fechado por elementos naturais como o Rio Grande e a Serra da Mantiqueira, bem como por Registros que impediriam, em tese, os descaminhos da produção e de impostos. O Rio Sapucaí, considerado então o limite entre os bispados de Mariana e São Paulo, é destacado no mapa e percebe-se a sobreposição das circunscrições eclesiásticas e civis, na delimitação do termo da vila. A legenda do mapa destaca que os seis pontos no Rio Grande, onde existem passagens ou pontes, são controlados pela Coroa. As distâncias em léguas da vila de Campanha até as freguesias que comporiam seu termo também estão explicitadas na legenda.

Na delimitação do seu termo, a Câmara de Campanha da Princesa continua em disputa com a Câmara de São João Del Rei; esta não concordava que as Freguesias de Lavras do Funil, Baependi e Pouso Alto pertencessem ao Termo da Vila de Campanha da Princesa. O governador da Capitania, Bernardo José de Lorena, sensível aos argumentos da Câmara de São João Del Rei, considerou que esta estava perdendo território muito extenso e que ficaria em extrema pobreza. Decide então que a Freguesia de Lavras do Funil deveria permanecer pertencendo a Vila de São João Del Rei (Araújo, 2008, p.137). Porém, a favor da Vila de Campanha, foi expedida uma Real Carta de Aviso comunicando que:

[...] o príncipe "tendo o generoso oferecimento que esta Câmara fez da terça parte das suas rendas para o Cofre de Sua Alteza Real a Princesa Nossa Senhora merecendo Vossas Mercês por esse motivo uma justa e particular contemplação da parte do Príncipe Regente Nosso Senhor". O regente ordenava ao Governador da Capitania, também por aviso, que se suspendesse "toda a divisão do território de que Vossas Mercês se queixam e que pusesse logo tudo no seu anterior estado". Isto passou a significar, para a Vila de Campanha, a posse de vasto território, representando praticamente toda a configuração do que posteriormente se denominaria Sul de Minas (Araújo, 2008, p.138).

Mas, além das disputas que se deram dentro da Capitania de Minas para a definição dos territórios dos termos das vilas de Campanha da Princesa e de São João del Rei, na Comarca do Rio das Mortes, a elevação da Vila de Campanha da Princesa precisa ser considerada como uma resposta estratégica da Capitania de Minas à elevação da Vila de Nova Bragança (atual cidade de Bragança Paulista), em 1797, pelo governador de São Paulo.

A análise das práticas e discursos envolvidos na elevação de freguesias ao estatuto de vila, em 1797, pelo então Governador da Capitania de São Paulo, Antonio Manoel de Castro e Mendonça (1797-1802), revela como este governo deu continuidade às estratégias de consolidação do 
território paulista inauguradas pelo governo de Dom Luís Antonio de Souza Botelho Mourão, o Morgado de Mateus (1765-1775). A elevação da freguesia de Jaguary, próxima ao registro homônimo, no território da Vila de Atibaia, estava vinculada aos conflitos e às definições de limites com a Capitania de Minas, no território estratégico junto ao caminho de Fernão Dias.

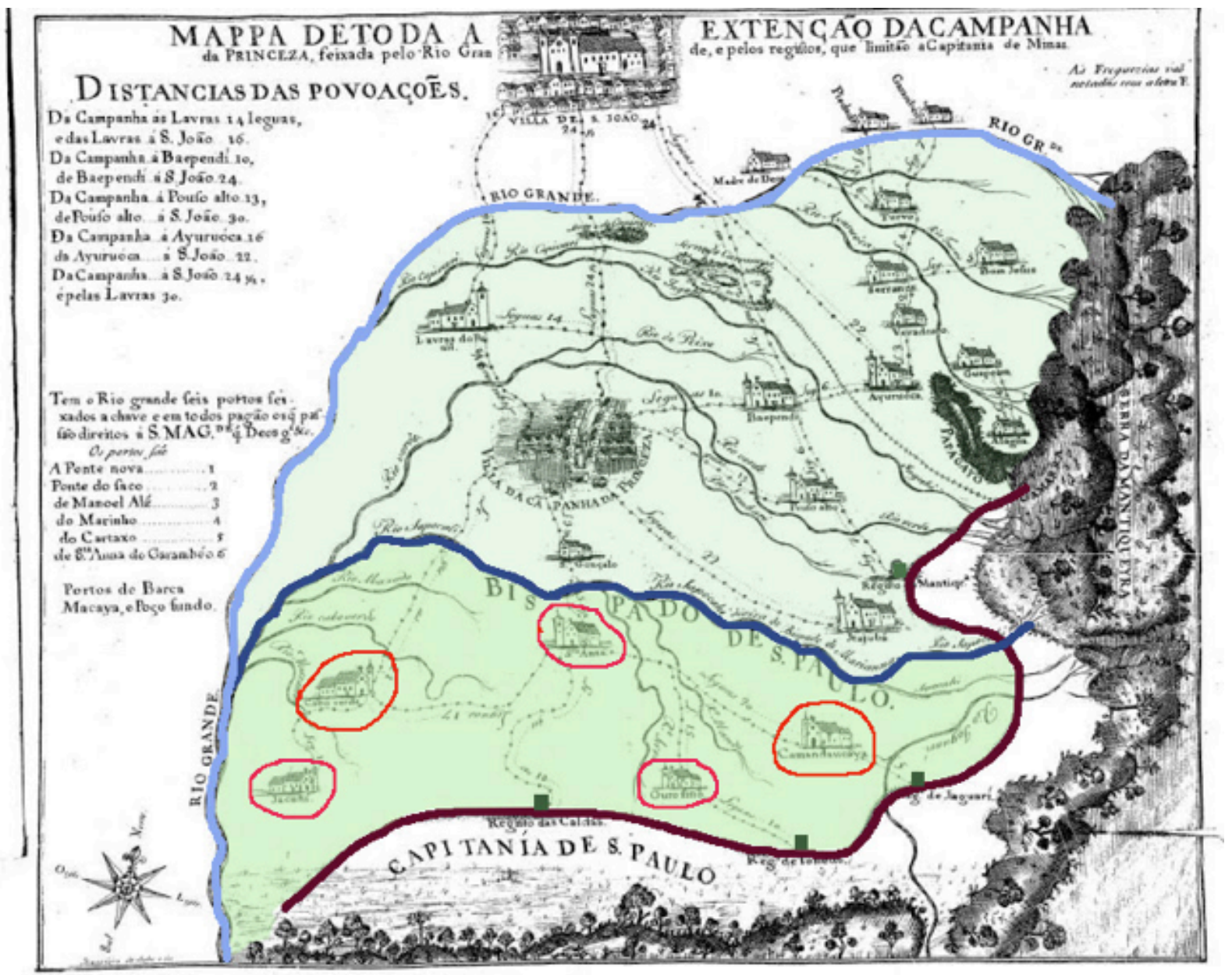

Figura 10. Imagem original manipulada pelas autoras, destacando os limites eclesiásticos entre os bispados de Minas Gerais e de São Paulo pelo o Rio Sapucaí (azul marinho), as freguesias no território do bispado de São Paulo (circundadas em vermelho), os limites civis entre as duas capitanias (em marrom) e os seus registros (quadrados verdes na linha marrom). Fonte: Mappa de toda a extenção da Campanha da Princeza feixada pelo Rio grande, e pelos registros, que limitão a Capitania de Minas, Capitão Francisco de Sales (ca. 1800), 35 x $41 \mathrm{~cm}$, manuscrito e aquarela, AHU (Arquivo Histórico Ultramarino), n.263/1170, originalmente incluído no códice n.2167, intitulado: "Livro de Creação da Campanha da Princeza”.

Em carta de 17 de agosto de 1797, remetida ao Secretário de Estado, Dom Rodrigo de Souza Coutinho, o Governador Castro e Mendonça se compromete a adotar "as medidas e o sistema de governo de seu antecessor", Bernardo José Maria Lorena e Silveira (1788 e 1797), no sentido de "promover a felicidade destes povos", de acordo com as instruções enviadas em 1796 (APESP. 1896, p.3).

O Relatório elaborado pelo Capitão General Bernardo José de Lorena descrevia o estado da Capitania de São Paulo na passagem do governo ao seu sucessor, bem como os principais instrumentos de controle da sua administração, entre eles o Mapa Corográfico da Capitania, no qual estavam descritos os limites, com as capitanias confinantes e com os domínios da Espanha.

Ocorre que, Bernardo José de Lorena foi designado como Governador da capitania de Minas Gerais, logo depois de deixar o governo de São Paulo. Ele, portanto, conhecia bem o território paulista e ao assumir o governo mineiro trata de favorecer a consolidação do território por parte de Minas na região de fronteira. A elevação de Campanha da Princesa responde a esta estratégia.

Os mapas das Figuras 11 e 12 mostram o território de divisa, próximo às vilas de Nova Bragança e Campanha da Princesa. 0 mapa da Figura 11 possui uma orientação invertida. Nela fica evidenciada a 
rede hídrica com destaque para os ríos Paraíba, Sapucaí, Verde, Baependi e Juruoca. Na parte superior do mapa destaca-se o vale do Rio Paraíba e sua rede urbana: as vilas de Resende e Areas, na Capitania do Rio de Janeiro; as vilas de Lorena, N. S. Aparecida, Guaratinguetá, Pindamonhangaba, Taubaté, São José e Jacarei, na Capitania de São Paulo. Na porção inferior do mapa é possível identificar a Vila de Campanha (10), o que revela a data aproximada do mapa, pois esta vila foi elevada em 1798. Constam no mapa os seguintes arraiais, que na elevação de Campanha à condição de vila eram freguesias pertencentes ao seu termo: Arraial de Baependi (4), Arraial de Itajubá (9), Arraial de São Gonçalo (11), Arraial de Santa Anna do Sapucaí (13), Arraial de Camanducaia (14).

O mapa, portanto, procura descrever a ocupação do termo da Vila de Campanha, logo após o seu desmembramento da Vila de São João del Rei, e destaca, além dos arraiais, os postos de controle: Registro da Mantiqueira (5), Registro de Itajubá (7) e Registro de Jaguari (15); Quartel das Bicas que se deve transferir (26), Lugar para o Quartel da Patrulha, Campos de São Pedro (20) e Quartel de São Paulo com guarda de ordenança da Vila de Pindamonhangaba (30). Também estão representados os acidentes geográficos: Monte Belesqueira Velha (1), Ita Piçú (2), Lagoa da Juruoca (3), Mata de Sapucaí Mirim (12), Morro do Lopo (16), Campos do Sertão de Camanducaia (17); as estradas: Estrada que sai da Mata de Sapucaí para a Vila da Pindamonhangaba (18), Estrada para Itajubá (24), Estrada para as Bicas (25), Estrada que segue da Vila de Campanha para a Vila de São João (31), Estrada que segue do Registro de Mantiqueira para a Vila de São João (32). A rede de fazendas também é apresentada e se articula a partir de derivações dos caminhos principais: Fazenda de João da Costa (27), Fazenda que foi do Calexo (28), Fazenda dos Pardos e Novos (29); Fazenda da Itapeba (19), Fazenda de Inácio Caetano (21), Fazenda de João Pereira (22). Em destaque ainda no mapa a Capela do Imbaú (6), o Lugar onde se deve transferir o Registro de Itajubá (8) e um local onde se localizavam Moradores de Itajubá (23).

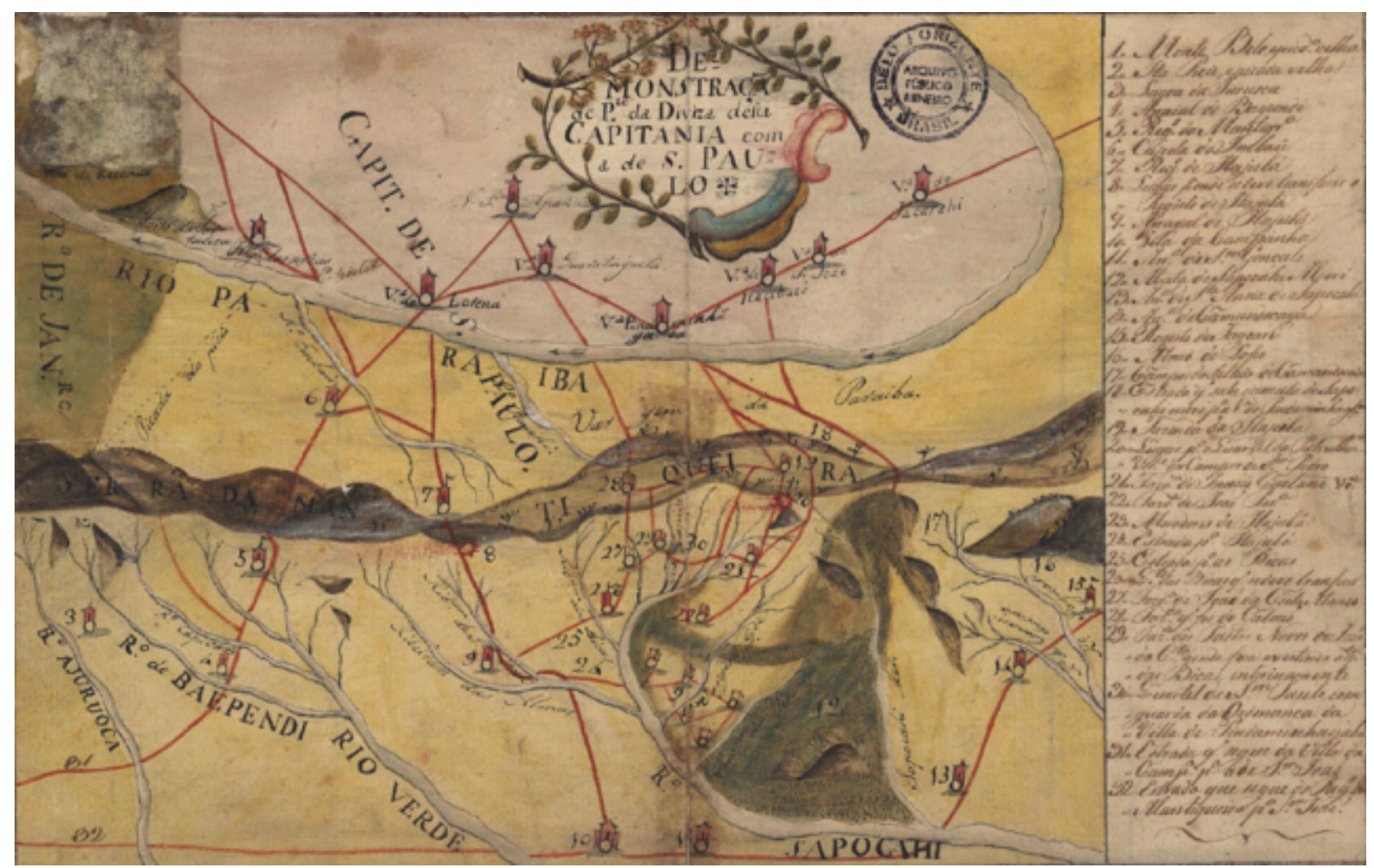

Figura 11. Mapa de demonstração da parte da divisa da Capitania de Minas Gerais com a de São Paulo - 1801 ( Data Provável ) - 21,0 x 32,0 cm. Fonte: Arquivo Público Mineiro - documentos cartográficos.

O mapa da figura 12 também foi elaborado sem atender as convenções cartográficas. Nele é possível perceber como a rede de caminhos entre a vila de Bragança (na parte superior do mapa) e o Rio Grande é pontuada por diversas formas de ocupação: a vila de Mogi Mirim, a freguesia de Mogi Guaçu, os arraiais de Ouro Fino (5), Cabo Verde (8),Jacuhy (13), além dos registros e guardas de controle das fronteiras - Registro de Jaguari (1), Registro de Campanha de Toledo (3), Registro de São Mateus ou Caconde da Capitania de São Paulo (10),guardas da Capitania de São Paulo (2 e 4), quartel da patrulha do Registro de Jacuhy (12) e Quartel da Caldas (6). 


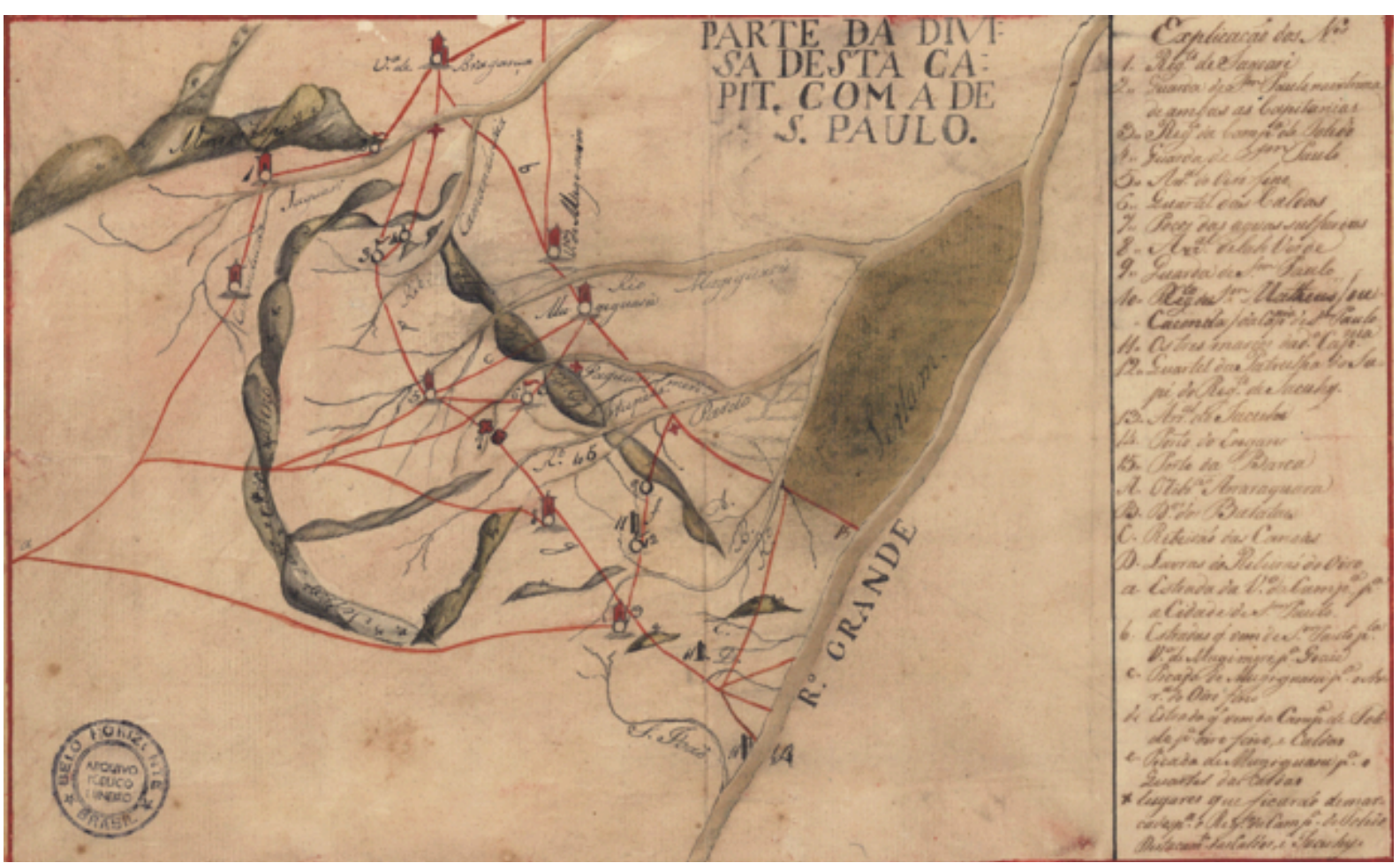

Figura 12. Mapa de parte da divisa da Capitania de Minas Gerais com a de São Paulo — 1801 (Data Provável) — 21,0 x $32,0 \mathrm{~cm}$. Fonte: APM documentos cartográficos.

Além dos documentos cartográficos, outros gêneros de documentos revelam a continuidade dos conflitos na região, mesmo após a elevação das vilas em questão, pois de fato a delimitação de seus termos ainda estava em aberto em alguns pontos. A representação da Câmara de Campanha da Princesa ao Governador de Minas, em 19 de setembro de 1800, pede providências a este, pois na divisa entre as capitanias, no local conhecido como Registro de Campanha de Toledo (marcado com o número 3 na legenda do mapa da Figura 12), se faziam entradas e se estabeleciam sítios e fazendas que ficavam sob a jurisdição da Vila de Bragança, mesmo que considerassem que as terras pertencessem à capitania de Minas?.

\section{Considerações finais}

Regiões de litígio, no século XVIII, os sertões do Rio das Mortes, do Rio Pardo e do Rio Grande foram marcados por estabelecimentos paulistas, estimulados pelo governo desta capitania, e pelas tentativas de ordenamento das autoridades coloniais mineiras visando a tomar posse dos arraiais encontrados. Os estudos de caso apresentados elucidam diferenças regionais em um mesmo contexto e fundamentam-se na documentação primária que representa os instrumentos de controle do território por parte da Coroa: a cartografia e os ofícios dos Governadores. Tais documentos revelam que, a medida que a ocupação dos sertões avançava, os litígios se deslocavam e percebe-se o reflexo das mudanças da política implementada pela Coroa no território colonial.

No processo histórico de definição das posses dos arraiais conquistados, o embate entre as duas capitanias, de Minas e de São Paulo, se fez a partir de disputas e por negociação em torno dos limites territoriais de cada uma delas. Aspectos geográficos, tratados como referências para o estabelecimento dos limites, estavam na pauta destas discussões e abrangeram o Morro do Caxambu, o alto da Serra da Mantiqueira, o Rio Verde, o Rio Sapucay, o Rio Grande, o Morro do Lopo e as margens da Estrada dos Goiazes. A definição destes limites implicava em negociações e conflitos em torno da incorporação de territórios junto aos descobertos, arraiais, capelas fundadas e freguesias formadas; envolviam também disputas entre os bispados de São Paulo e Mariana.

\footnotetext{
${ }^{7}$ Arquivo Público Mineiro, SG CX. 48 DOC 61.
} 
No período analisado, parte do território permanece, portanto, sob jurisdição civil da Capitania de Minas, mas subordinado ao Bispado de São Paulo, e outra parte dos territórios fica sob jurisdição civil da Capitania de Minas e subordinado ao Bispado de Mariana. Quando Campanha da Princesa é elevada a vila, em 1798, o território de seu termo em litígio praticamente correspondeu ao que havia sido a Comarca do Rio das Mortes da Capitania de Minas Gerais e abrangeu, na sua formação, dez freguesias, cinco delas pertencendo ao bispado de São Paulo (Santana do Sapucaí, Camanducaia, Ouro Fino, Itajubá, Cabo Verde e Jacuí) e as outras cinco, pertencendo ao bispado de Mariana (além da própria freguesia de Campanha, Lavras do Funil, Baependi, Pouso Alto e Itajubá).

No território em questão, ou seja, na região de fronteira com as Capitanias de São Paulo e de Minas Gerais, as disputas pela definição dos termos das vilas se instalam à medida que a ocupação avança. Os primeiros litígios envolvem a definição dos limites dos termos entre a vila de Guaratinguetá, no Vale do Paraíba, e a vila de São João del Rei, na Comarca do Rio das Mortes. Moradores de outras vilas do Vale do Paraíba, como Taubaté, Jacareí e Mogi das Cruzes, se envolvem nos conflitos pela posse dos descobertos além da Serra da Mantiqueira, como os casos de Carrancas, Baependi, Pouso Alto, Itajubá, Airuoca, Camanducaia, Santana do Sapucaí e Ouro Fino. No sentido do caminho dos Guayases, as vilas de Jundiaí e depois Mogi-Mirim, reivindicam a posse de Cabo Verde, Jacui e do Descoberto da região do Desemboque; todos estes palcos de disputas, entre paulistas e mineiros, em torno de descobertos e arraiais de mineração.

É a partir das vilas que se estrutura a tomada de posse dos territórios. Os exemplos analisados demonstram que os agentes do poder civil - ouvidores, juízes e capitães de tropas de ordenanças - ou do poder eclesiástico, oficializaram as posses em nome das vilas das quais se originam.

Embora a Capitania de São Paulo tenha perdido sua autonomia, entre 1748 e 1765, o bispado de São Paulo manteve sob seu controle as freguesias fundadas por paulistas a oeste do Rio Sapucaí. Durante esse período, é evidente o avanço das autoridades civis mineiras sobre o território antes ocupado pelos paulistas e, apesar do empenho de Dom Luís Antonio de Sousa Botelho de Mourão, para reverter tal quadro, não houve apoio por parte da Coroa para que os limites civis da capitania de Minas recuassem até a linha do Rio Sapucaí.

\section{Referências}

Araújo, P. V. L. de (2008). Vila de Campanha da Princesa: Urbanidade e Civilidade em Minas Gerais do século XIX (1798-1840). (Tese de Doutorado) Universidade Estadual de Campinas, Instituto de Filosofia e Ciências Humanas, Campinas, SP, Brasil.

Arquivo Público do Estado de São Paulo - AESP (1896). Documentos Interessantes para a história e costumes de São Paulo. Divisas de São Paulo e Minas Gerais. Vol. 11. São Paulo: Typographia Espindola Siqueira e Comp.

Barbosa, W. de A. (1971). Dicionário histórico-geográfico de Minas Gerais. Belo Horizonte: Editora Saters.

Bellotto, H. L. (2007). Autoridade e conflito no Brasil colonial: o Governo do Morgado de Mateus em São Paulo (1755-1775). São Paulo: Editora Alameda.

Bueno, B. P. S. (2009). Dilatação dos confins: caminhos, vilas e cidades na formação da Capitania de São Paulo (1532-1822). In Anais do Museu Paulista 17 (2), São Paulo, pp. 251-294.

Chiachiri Filho, J. (1986). Do Sertão do Rio Pardo à Vila Franca do Imperador. Ribeirão Preto: Ribeirão Gráfica e Editora Ltda.

Costa, A. G. (org.) (2007). Roteiro prático de cartografia: da América portuguesa ao Brasil Império. Belo Horizonte: Editora UFMG.

Cruz, C. F. (2010). Fazendas do sul de Minas Gerais. Arquitetura rural nos séculos XVIII e XIX. Brasília: IPHAN (Programa Monumenta).

(C) Labor \& Engenho, Campinas [SP] Brasil, v.11, n.3, p.218-241, jul./set. 2017. 
Fonseca, C. D. (2011). Arraiais e vilas D`El Rei: espaço e poder nas Minas setecentistas. Belo Horizonte: Editora UFMG.

Marx, M. (1991). Cidade no Brasil: terra de quem? São Paulo: Nobel; Editora da Universidade de São Paulo.

Moraes, F. B. de (2006). A rede urbana das Minas coloniais: na urdidura do tempo e do espaço. (Tese de Doutorado). Universidade de São Paulo, Faculdade de Arquitetura e Urbanismo, São Paulo, SP, Brasil.

Ottoni, H. B. (1960). Poços de Caldas. São Paulo: Editora Anhambi.

Piccinato, D., Jr. \& Salgado, I. (2014). Conflitos políticos e articulações sociais: a história dos limites entre São Paulo e Minas Gerais na formação do território nordeste paulista - 1720-1935. Paranoá. Cadernos de Arquitetura e Urbanismo, n. 13, pp. 9-16.

Souza, Ney de (2004). Catolicismo em São Paulo: 450 anos de presença da Igreja Católica em São Paulo. São Paulo: Edições Paulinas; Pia Sociedade Filhas de São Paulo.

Trindade, Cônego Raimundo (1945). Instituições de Igrejas do Bispado de Mariana. Rio de Janeiro: SPHAN/ MES/ Imprensa Nacional.

Valladão, A. (1937). Campanha da Princeza. Rio de Janeiro: Leuzinger. 